Historic, Archive Document

Do not assume content reflects current scientific knowledge, policies, or practices. 



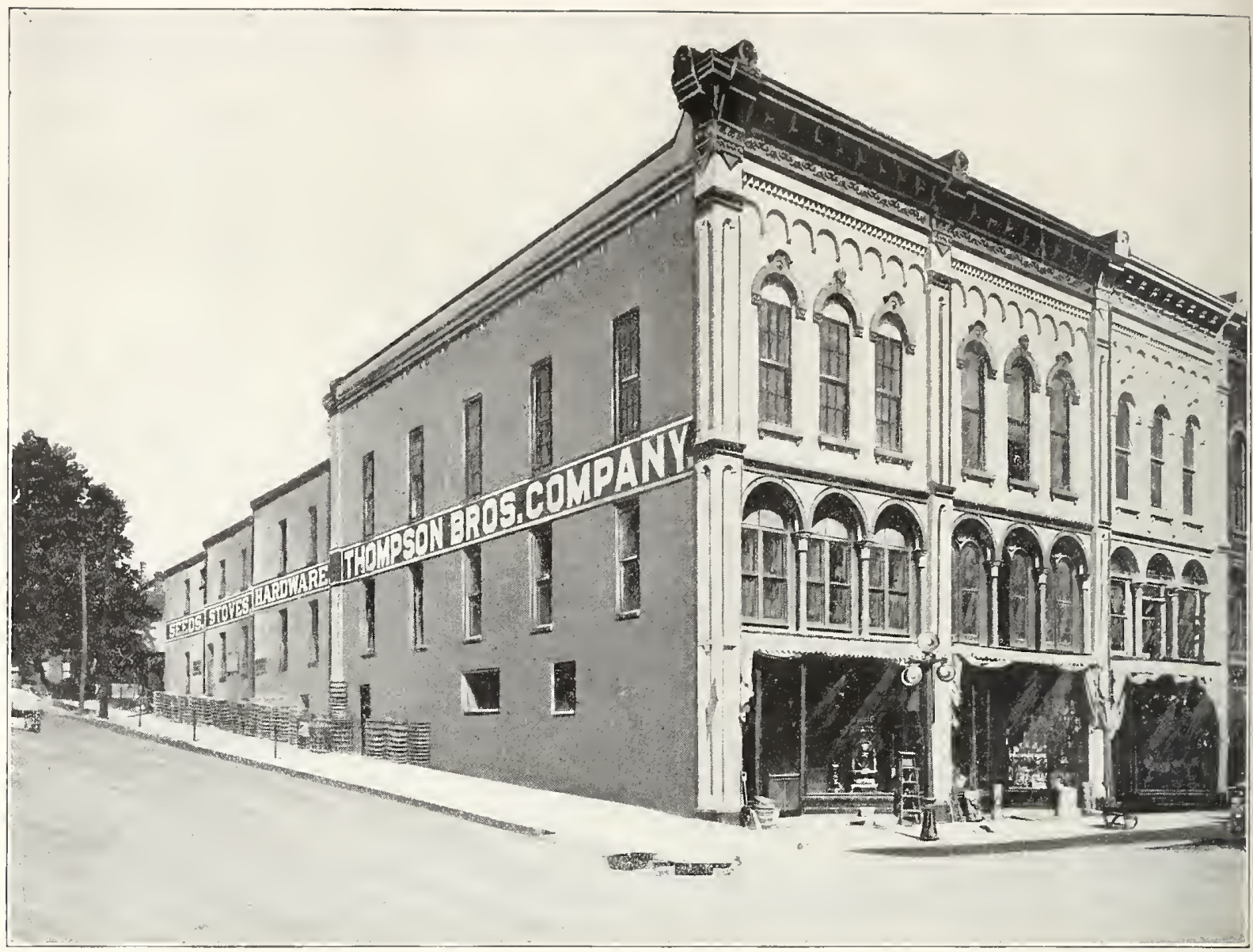

This list is published for the purpose of acquainting our customers with the stocks we carry, and to give them an approximate idea of the cost of such articles. Good seeds, seeds that have a value are constantly changing in price, like hogs, cattle, wheat, etc. For this reason a great many articles here listed Feb. 1st may be selling at a lower price by the time you are ready to buy. We do, however, endeavor, as much as possible, to maintain the list prices clear through on goods in small quantities like pints, quarts, packets and ounces.

\section{SPEOIAL NOTIOE}

Owing to a possibility of errors, or failure of seed to grow, over which we have no control, we hereby in common with all other Seedsmen, give no warranty, expressed or implied, as to deseription, purity or productiveness of any seed we sell. If the purchaser does not accept them on these terms, they must be returned at once and the amount paid for them will be refunded.

Notice Carefully the Prices-Be sure to know whether we or you are to pay the freight or express, and bear in mind that we do not pay the express or freight charges on pecks or bushels, nor on any tools or plants, nor on potatoes, grass seeds, field seeds or fertilizers, except where we so state on the pages where the goods are priced.

We pay Postage or Expressage on all seeds quoted by the packet, ounce, quarter pound and pound, also on pints and quarts of Peas, Beans and Sweet Corn, and upon all goods quoted in our catalogue where it says: "I'pepaid by mail or Express."

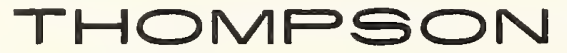

Store: 131 and $133 \mathrm{~W}$. Second Street

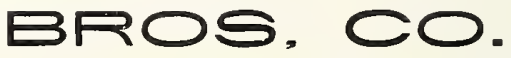

Warehouse: 211-213 Chestnut St.

\section{MUSCATINE, IOWA}

The descriptions of all seeds will be found in alphabetical order in the Catalogue beginning at Page 1. Where no price is given in the price list it indicates that the article is in very short supply and that it will be to the advantage of the buyer to ask for a special price. Grass Seeds, Clover and all varieties of field seeds vary so much that we find it more satisfactory to have the buyer write for the market price. 


\section{GARDEN SEEDS-..POST PAID}

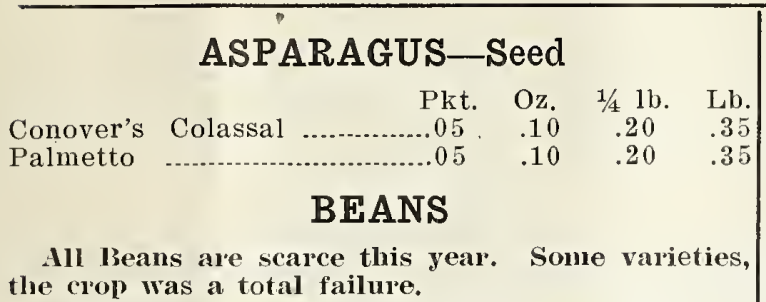

\section{Dwarf, Bush or Snap, Green Podded Varieties}

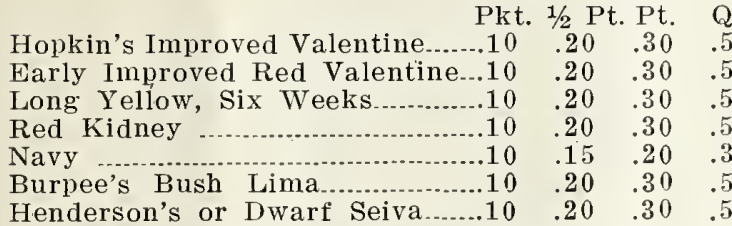

\section{Dwarf, Bush or Snap, Wax Podded Varieties}

Davis White Wax Crop Failed

Golden Wax Crop Failed Improved Golden Wax, Rust Proof......Crop Failed Black Wax .................................................... Failed Wardwell's Kidney Wax

\section{Pole or Running} Crop Faile

White Creaseback Pkt. $1 / 2$ Pt. Pt.

Red Speckled Cut Short or Corn

$$
\text { Hill }
$$

Kentucky Wonder or old Home-

Lazy Wife

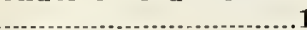

Large White Lima

King of the Garden Lima............10 $\quad .15 \quad .30$

Early Dutch Case Knife...........10 15.15 Peck and Bushel Values Vary. Write for prices.

\section{BEETS-For the Table}

Pkt. Oz, 1/4 Lb. I.b. Early Eclipse Lentz Early Blood Turnip..........05 .10 Long Smooth Dark Blood..........05 .10

\section{Beets-Mangel Wurzels}

Long Red Pkt. Oz. $1 / 4$ Lb. Lb. Gold Tankard

$\begin{array}{llll}.05 & .10 & .15 & 35\end{array}$
$\begin{array}{llll}.05 & .10 & .15 & .35\end{array}$

\section{Beets-Sugar}

Pkt. Oz. $1 / 4$ Lb. Lb Lane's Imperial Sugar............05 $.10^{1 / 20} \quad .35$ $\begin{array}{llll}\text { Vilmorin's Improved Sugar.........05 } & .10 & .20 & .35 \\ \text { Kly }\end{array}$ Klein Wanzleben

$\begin{array}{llll}05 & .10 & .20 & .35\end{array}$

\section{BROCCOLI}

White Cape

Pkt. Oz. $1 / 4 \mathrm{Lb}$

Purple Cape
$.05 \quad .30$

$.05 \quad .30$

\section{BRUSSELS SPROUTS}

Pkt. Oz. 1/4 Lb. Lb. $\begin{array}{llll}.05 & .20 & .50 & \$ 1.50\end{array}$

\section{CABBAGE}

Pkt. Oz. $1 / 4 \mathrm{Lb}$. Lb.

Early Jersey Wakefield ......05 $\quad .20 \quad \$ 0.60 \quad \$ 2.00$

\begin{tabular}{|c|c|c|}
\hline mer & .20 & .60 \\
\hline All Head Early ... & .20 & .60 \\
\hline All Seasons & .20 & .60 \\
\hline uccession & .20 & .60 \\
\hline Early Dwarf Flat Dutch & .20 & .60 \\
\hline Early Winningstadt .........05 & .20 & .60 \\
\hline $\begin{array}{l}\text { Glory of Enkhuisen, Im- } \\
\text { ported Stock }\end{array}$ & .25 & .75 \\
\hline $\begin{array}{l}\text { Copenhagen Market, Im- } \\
\text { ported Stock }\end{array}$ & .25 & .75 \\
\hline remium Late Flat Dutch .05 & .15 & .45 \\
\hline urehead & .20 & .60 \\
\hline $\begin{array}{l}\text { Holland Short Stem Strain, } \\
\text { Imported Stock }\end{array}$ & & \\
\hline Red Dutch .......... & & \\
\hline
\end{tabular}

Henderson's E a r 1 y Sum-

\section{CARROT}

Pkt. Oz, 1/4 Lb. Lb.

Early Scarlet Horn _...........05 05

Half Long Nantes ............05 .10

Geurande or Ox Heart $05 \quad 10$

Danvers ............................. $05 \quad .10$

Half Long Scarlet Caren-

$\tan$

Improved Long Orange $\ldots . . .05 \quad .10 \quad .25 \quad .75$

Long White Belgian ...........05 .10 .25

\section{CAULIFLOWER}

Pkt. Oz.

$1 / 4 \mathrm{Lb} . \mathrm{Lb}$

Early Snowball

$15 \quad 1.50$

Earliest Dwarf Erfurt .......15 1.50

\section{CELERY}

$00 \$ 20.00$

$5.00 \quad 20.00$

Golden Self-blanching $\quad . . . . .10 \quad .50 \quad 1.50 \quad 5.00$

White Plume $\ldots . . . .05 \quad .15 \quad .40 \quad 1.25$

$.40 \quad 1.25$

$40 \quad 1.25$

$.40 \quad 1.25$

.351 .00

CORN SALAD

Pkt. Oz. $1 / 4 \mathrm{Lb}$.

Large Seeded, Large Leaved.......05 .10 .15

\section{SWEET CORN}

White Cob Cory

Pkt, Pt. Qt

Early Minnesota

Early Evergreen ............................ 05

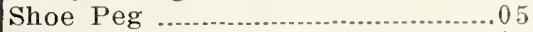

Country Gentleman ...................05

Golden Bantam …...05

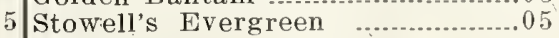

.75 Mammoth

.05 


\section{CORN-Popping}

$1 / 4 \mathrm{Lb} . \quad \mathrm{Lb}$.

White Rice, Shelled

.10

51 Pearl Shelled

10

\section{CRESS}

Curled or Pepper Grass .05 True Water

10 Lb.
.25
.25

\section{LETTUCE}

Pkt. Oz. 1/4 Lb. Lb. Black Seeded Simpson Grand Rapids, B. S. ...........05 050 .10 $.20 \quad .65$ Early Curled $\mathrm{S}$ i m p s o n,

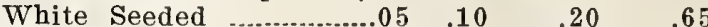
Denver Market, W. S. ........05 $\quad .10 \quad .20 \quad .65$

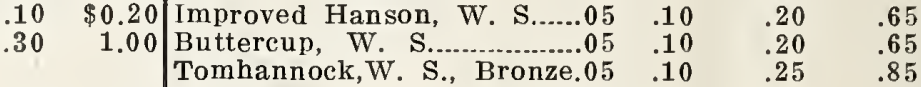

\section{CUCUMBER}

Oak Leaf

$05 \quad .10$

.20

\section{MIUSKMELON}

Early Cluster

Pkt. Oz. $\quad 1 / 4 \mathrm{Lb} . \quad \mathrm{Lb}$.

Green Prolific or Boston

Pickling .......................... $05 \quad .10 \quad .20$

Early Frame or $\mathrm{S} \mathrm{h} \mathrm{o} \mathrm{r} \mathrm{t}$

Green ............................05 $\quad .10 \quad .20$

Chicago Pickle, W e s t e r-

field's

$05 \quad .10 \quad 20$

Improved Long Green ......05 .10 $\quad .20$

Early Improved $W$ h i t e Spine

$\begin{array}{lll}.05 & .10 \quad .20\end{array}$

\section{EGG PLANT}

Improved New York, Purple

Pkt. Oz. 1/4 Lb.

-Spineless

.05

.90

\section{ENDIVE}

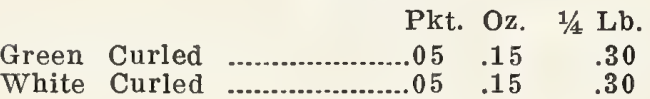

\section{GOURDS}

Dipper

\section{Pk}

Fancy Varities, Mixed

.05

\section{HFRBS}

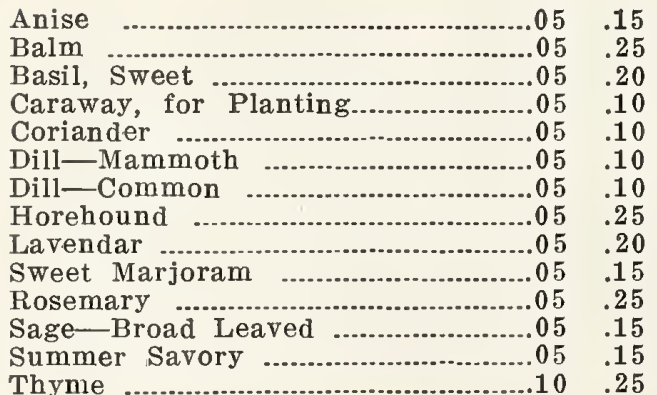

\section{KALE}

Pkt. Oz. $1 / 4 \mathrm{Lb}$.

Dwarf Curled Scotch .........05 $.10 \quad .20$

Tall Curled Scotch .............05 .105

\section{KOHL-RABI}

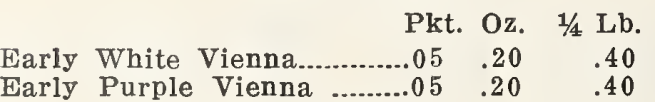

\section{LEEK}

London Flag

Pkt. Oz. $1 / 4 \mathrm{Lb}$.

1.50

Lb.

.90 Tom Watson

WATERMELON

Prices on Muskmelon: do not hold. ASK FOR PRICES.

.65

.65

rell's Gem

Pkt. Oz. $1 / 4 \mathrm{Lb} . \quad \mathrm{Lb}$.

.65

.65

Esmera

Rocky For

$.05 \quad .10$

arly Hackensack ….........05 $\quad .10$

dmiral Togo

Jenny Lind

Lb.

3.50

Prices on Watermelon do not hold. ASK FOR PRICES.

90 Kleckly Sweets, same as

Monte Cristo ..................05 .10 $.20 \quad 50$

Light Icing ........................05 $.10 \quad .20 \quad .50$

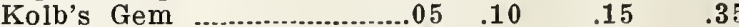

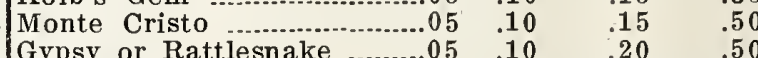

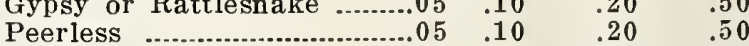

Sweetheart $\quad . . . . . . . . . \ldots \ldots \ldots \ldots . . . . .05 \quad .10 \quad .20 \quad .50$

MUSTARD

$1 / 4 \mathrm{Lb}$

....

.20

Black (Wild)

Pkt. 1/4 Lb. Lb.

.20

.20

.20

.... Tall or Garden

.40 Dwarf Mixed

40

.40
.40
1.00

1.00

Lb.
.60
.60

White, Lond on

\section{NASTURTIUM}

Pkt. Oz. $1 / 4 \mathrm{Lb}$. Lb.

$\begin{array}{llll}.05 & .10 & .20 & .50\end{array}$

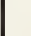

ONION SEFD

Pkt. Oz, $1 / 4$ Lb. Lb.

$\begin{array}{llll}\text { Southport Red Globe .........05 } & .15 & .40 & 2.0 .0 \\ \text { Large Red Wethersfield.......05 } & .15 & .75 & 2.50\end{array}$

Early Flat Yellow Danvers...05 $\quad .15 \quad .70 \quad 2.25$

Yellow Globe Danvers .......05 $\quad .15 \quad .70 \quad 2.25$

Philadelphia Silver Skin...05 $\quad .25 \quad .90 \quad 3.25$

Prize Taker ........................05 $\quad .15 \quad .70 \quad 2.25$

White Barletta .................. $05 \quad .20 \quad .80 \quad 2.75$

Lb.

1.50

\section{ONION SETS}

Red Bottom Sets, $1 / 2$ pints, any kind

Post Paid

White Bottom Sets, pints, any kind................ .15

Yellow Bottom Sets, quarts, any kind.............. . .25

Lb. Genuine Top Sets ......................................... .25

1.50 Bushel and peck, write for market prices. 


\section{PARSLEY}

' Pkt. Oz. 1/4 Lb. $\begin{array}{lll}05 & .10 & .20\end{array}$

Plain or Single

$.05 \quad .10 \quad .20$

\section{PARSNIP}

Pkt. Oz. 1/4 Lb. Improved Hollow Crown.....05 .10 .15

\section{PEAS-Smooth Seed}

Smooth Seed Peas, 60 lbs. to Bushel Pkt. 1/2 Pt. Pt.

Alaska

$15 \quad 20$

First and Best $.10 \quad .15$

Early May

Extra Early

.15

.20

Telegraph

$.10 \quad .15$

Tom Thumb

$.10 \quad .15$

White Marrowfat

10

.15

.15

.20

Telephone

Pride of Market

\section{PEAS-Wrinkled Seed}

Wrinkled Seed Peas, 56 lbs. to Bushel Pkt. $1 / 2$ Pt. Pt.

American Wonder ...............10 $10 \quad .15 \quad .20$

Abundance

Gems, Premium _............10 .15 .20

Dwarf Gray Sugar _...........10 $\quad .15 \quad .20$

Peck and bushel price of Peas vary, write for prices.

\begin{tabular}{|c|c|c|c|}
\hline \multicolumn{4}{|c|}{ PEPPER } \\
\hline Long Cayenne & $\begin{array}{l}\text { Pkt. } \\
.05\end{array}$ & $\begin{array}{l}\mathrm{Oz} . \\
.20\end{array}$ & $\begin{array}{c}1 / 4 \mathrm{Lb} . \\
.50\end{array}$ \\
\hline Red Chili ... &. .05 & .20 & .50 \\
\hline Bell or Bull Nose & .05 & .20 & .50 \\
\hline Sweet Mountain & $\ldots 05$ & .20 & .50 \\
\hline Ruby King & .05 & .20 & .50 \\
\hline Golden Dawn &. .05 & .20 & .50 \\
\hline
\end{tabular}

\section{PUMPKIN}

Pkt. Oz. $1 / 4 \mathrm{Lb}$.

Small Sugar

$.05 \quad .10$

Mammoth Sugar

$.05 \quad .10$

.20

Connecticut Field

$.10 \quad .15$

\section{RADISH}

Scarlet Turnip White Tipped Forcing

Early Scarlet Globe, the
best forcing variety .......

Long Scarlet Short Top........

White Icicle ..........................

Early Scarlet Turnip ..........

Deep Scarlet Turnip .......

Turnip ............................

French Breakfast ...............05

Early White Turnip ........05

Long Brightest Scarlet .......05

Improved Chartier .............05

Crimson Giant ......................05

Long White Vienna or Lady Finger ......................05

White Strasburg .................05

White Summer Turnip .......05

White Stuttgart ................05

Yellow Summer Turnip .....05

Rose China Winter ..............05

Large White Spanish ..........05

Long Black Spanish

Lb.

Lb.

.35

.35

.35

.40

Qt.

.35

.35
.35

for

$\mathrm{Lb}$.

$\mathrm{Lb}$.
75 Victoria

.75 Linnaeus

.45

Mammoth Sandwish Island..

SPINACH

(Ro

$35 \mathrm{R}$

35

.

.35

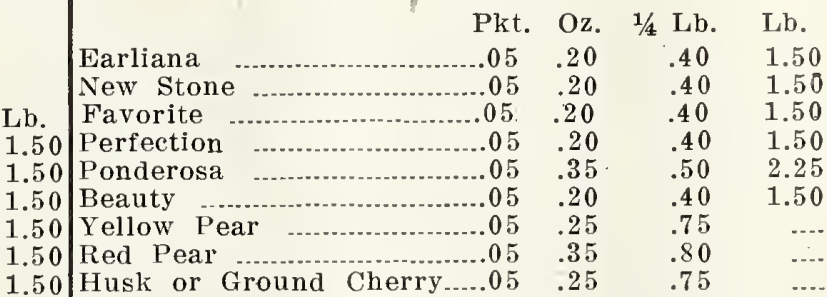

\section{RUTA BAGA}

.50 Improved American Purple

.50 Top .............................. $05 \quad .10 \quad .15 \quad .40$

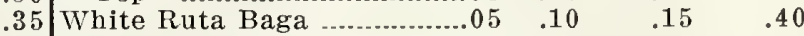

\section{TURNIP}

.45

Extra Early White Milan.....05 $050 \quad .20 \quad .75$

Strap Leaved ...............05 $.10 \quad .15$
Strap

45 Early Purple Top, Strap

45 Leaved ........................ 05 .10

45 Purple Top White Globe $05-10 \quad .15$

\begin{tabular}{l|llll}
.45 & Purple Top White Globe....05 & .10 & .15 & .35 \\
Cow Horn or Long White...05 & .10 & .15 & .35
\end{tabular}

45 Cow Horn or Long White...05 .10 .15

45 Sweet German ..................05 $\quad .10 \quad .15 \quad .35$
All prices for Garden Seed, except where noted, are for the Seeds Prepaid to your postoffice or express office.

.45

.45

.455 Canary

BIRD SEEDS

Post Paid

45 Hemp

.45 Millet

45 Rape, German Bird -.......... 15

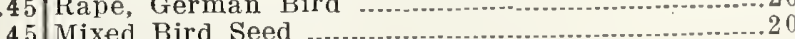

.45 Sunflower

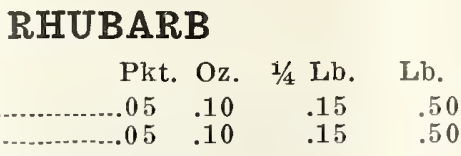

80 .90

30

30
30 b. 75 .75 70 $\mathrm{Oz}$ 5

$\begin{array}{ll}\text { Pkt. } & \text { Oz. } \\ & .25\end{array}$

: 


\section{DESCR}

Giant or Palmetto Asparagus

A very large, early rapid growing variety; producing even perfect roots in abundance. It is well adapted to every state. Grows soon from seed.

\section{Conover's Colossal Asparagus}

A very large valuable variety. Make the soil lich and stir deep. It is one of the best large hardy varieties that we have. Sprinkle in the ground with salt in the spring and keep soil moist.

\section{BUSH BEANS}

\section{Wardwell's Kidney Wax}

Hardy and productive, pods long, broad, thick, flat, and of a delicate waxy yellow, of excellent quality and with no string in the early growth, ready to pick 49 days from planting.

\section{Golden Wax}

The old standard wax sort. Productive and early with yellow semi-round pods of good quality, ready to pick 49 days from planting.

\section{Improved Golden Wax}

Rust proof, an improvement on the old style Golden Wax. Pod is semi-round, yellow, of good quality and has no string. Ready for picking 47 days from planting.

\section{Davis White Wax}

This bean is adapted alike for the canner, market gardener, shipper or amateur. The dry bean is large, kidney shaped, and white in color, making it one of the best for cooking in a dry state. Pods are long, meaty, flat in shape, and of a beautiful yellow color and fair quality.

\section{Prolific Black Wax}

The old standard Black Wax Bush Bean. It is so good that it is worthy of special notice. The pods are round, brittle, of handsome golden yellow color, and of buttery flavor when cooked.

\section{Extra Early Red Valentine}

Hardy, pods light green, and semi-transparent round and slightly curved. Succulent, prolific, and quite free from strings, continuing long in an edible condition; 46 days from planting to first picking.

\section{Long Yellow Six Weeks}

The vine is large, vigorous, branching and productive, with large leaves. Pods long, straight, thick, flat in shape, green in color, of good quality when young and fair as they near maturity. Is ready for picking 45 days from planting.

\section{DWARF LIMA VARIETIES}

\section{Burpee's}

The only bush form of the true, luscious large lima. It is pronounced by all good judges as un-

questionably the real Bush Lima. The bushes grow eighteen to twenty inches high, of stout growth and always erect. It is an immense yielder.

\section{Henderson's}

This is a bush form of the small Seiva pole bean. It is the original bush form of the pole beans. It is the most productive of any, and on the whole is a vegetable of great merit.

\section{Small White Lima, Carolina or Sieva}

Vines vigorous with many short branches, so that they are sometimes grown without poles; very early and productive, bearing short pods, which are thin and curved.

\section{POLE BEANS}

\section{Kentucky Wonder}

Vines vigorous, climbing well, and very productive, bearing its pods in Iarge clusters, blossoms white; pod green, very long, often reaching 9 to 10 inches. Nearly round when young and very crisp, although as they reach maturity they become irregular and spongy. Dry beans long, oval, dun-colored.

\section{Lazy Wife}

One of the most productive and easily gath ered of the Pole Beans, hence its very discourteous name. A most excellent bean for the home garden.

\section{Early Jersey Lima}

Ten days earlier than any other Lima. Recommended as a most profitable Lima Beall.

\section{King of the Garden Lima}

The old standard market and family sort. The vine begins to produce pods at the foot of the pole, and the bearing season continues until frost. Pods large, and well filled with beans of mammoth size.

\section{Large White Lima}

The large Lima is a general favorite wherever it can be cultivated, on account of its excellent flavor and productiveness.

\section{Red Speckled Cut Short (or Corn Hill}

This is the best sort to plant in hills of corn. A great cropper.

\section{Dutch Case Knife}

Vines moderately vigorous climbing well and excellent for a corn hill bean; leaves large, crumpled, and pods very long, flat, green in color, becoming creamy white later. Beans broad kidney shaped, flat and white in color.

\section{White Creaseback}

An extremely early Pole Bean. Vines small to medium and wonderfully productive. Bearing pods in clusters of from 4 to 12 , and medium in length. An excellent shipper. 


\section{TABLE BEETS}

Early Eclipse

A choice early variety; well known and popular. Shape, globular; quality, good; color, light.

\section{Early Egyptian}

The well-known early variety. Color, extra dark; shape, flat; quality, excellent.

\section{Lentz Extra Early Blood Turnip}

A favorit market-gardeners' beet around Philadelphia. Very early and sweet; ringed red and white.

\section{Improved Blood Turnip}

An improved variety of the Early Blood turnip of deep, blood-red color; fine form and flavor. An excellent market sort.

\section{Long Smooth Blood}

The standard long late sort. Very dark, bloodred flesh; quality fine.

\section{SUGAR BEETS}

\section{Vilmorin's Improved Sugar}

In general, the most desirable beet for the factory is the one containing the largest percentage of sugar.

\section{Klein Wanzleben}

A little larger than Vilmorin's Improved, yielding from twelve to eighteen tons per acre, and containing about the same amount of sugar. It grows below the surface, and the green leaves are rather large and spreading.

\section{Lane's Imperial Sugar}

Good for making sugar, also stock feeding. A hardy and productive sort. Yields fourteen to sixteen tons per acre, and contains about 16 per cent of sugar.

\section{STOCK BEETS}

\section{Improved Mammoth Long Red}

The largest and most productive variety. Immense crops can be grown from it.

\section{Golden Tankard}

Shape cylindrical, color deep rich yellow, flesh yellow circled with white. Unequalled for feeding stock.$$
\text { CABBAGE }
$$

\section{Early Jersey Wakefield Cabbage}

Selected stock. This is one of the most important varieties in the list. Great care must be exercised in the growing of the seed to have it pure and true to type.

\section{Copenhagen Market}

A new early variety, popular with market gardeners. It is one of the finest early round-headed cabbage in cultivation. It is desirable on account of the remarkable characteristics of maturing the heads all at the same time, enabling the grower to gather his crop with less expense and permitting the cleaning of the land at the first cutting. The heads average about ten pounds each in weight, are hard and solid with small core. The quality is extra fine and sweet. It is a short stemmed variety, the heads nearly resting on the ground. The leaves are light green, rather small, saucer-shaped and tightly folded, making it possible to set them close together in the field.

\section{Glory of Enkhuizen}

This is an excellent mid-summer variety. It comes in about a week earlier that All Seasons, makes a nice large head, has few outer leaves and can be planted close. Tests show it to be worthy of a place among the new varieties of merit and we can recommend it as a good addition to the list.

\section{Henderson's Early Summer}

A standard summer variety. We have the true stock.

\section{Henderson's Succession}

A good summer cabbage; also makes a good cabbage to succeed itself.

\section{Early Winningstadt}

An early variety of excellent quality, not as early as the Wakefield.

\section{All Head Early}

One of the finest early flat-head cabbages.

\section{Early Dwarf Flat Dutch}

An early cabbage of good size. Heads are flat and very solid.

\section{All Seasons}

A fine variety for any season, of good shape and size.

\section{The Holland Cabbage}

The heaviest cabbage for the size of head ever introduced.

\section{Sure Head}

A fine variety for main crop. A good shipper and sure header.

\section{Premium Flat Dutch}

This variety of late cabbage is a standard in all sections for winter use.

\section{CARROTS}

\section{Early Short Horn}

Excellent for early planting out of doors. Tops small, coarsely divided; roots top-shaped, but tapering abruptly to a small tap, skin orange-red.

\section{Guerande, or Ox Heart}

Tops small for the size of the roots which are comparatively short but often reach a diameter of 5 inches, terminating abruptly in a small tap root. Flesh bright orange, fine grained and sweet. This variety is especially desirable for soil so hard and stiff that longer rooted sorts would not thrive in it. When young excellent for table use, and when mature equally good for stock. 


\section{Danvers}

Grown largely on account of its great productiveness and adaptability to all classes of soil. Tops of medium size, coarsely divided. The smooth and handsome roots are deep orange, of medium length, tapering uniformly to a blunt point; flesh sweet, crisp, tender and of a deep orange color. Although the roots of this variety are short, they produce as large a bulk as the longer field sorts and are more easily harvested.

\section{Long Orange}

The most popular of the older sorts for farm use on mellow soil. An improvement obtained by years of careful selection of the best formed and deepest colored roots.

\section{White Belgian}

Grows one-third out of the ground. Root white, green above ground, with small top. Flesh rather coarse. The roots are of large size and the variety is extensively grown for stock feeding.

\section{CAULIFLOWER}

\section{Snowball}

The leading cauliflower and unquestionably the purest strain of "Snowball" cauliflower seed to be had. Heads uniform; of desirable market size and of snowy whiteness.

\section{Earliest Erfurt}

A variety that has given excellent satisfaction to our home gardeners. It is snow white and a sure header. Gardeners will be amply repaid by giving this variety a fair trial.

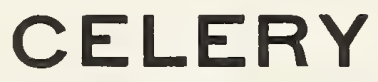

\section{Golden Self Blanching}

The best of all early self-blanching varieties. First introduced in America in 1884, this is decidedly better in quality than the White Plume. It is ready for use nearly as early, blanches. easily, and is larger in size as well as finer in quality. It is of dwarf compact habit, with thick, solid, heavily ribbed stalks which blanch easily to a clear waxen yellow.

\section{Giant Pascal}

This is a green leaved variety developed from the Golden Yellow Self Blanching, and is an excellent sort for fall and winter use. It blanches to a beautiful yellowish-white color, is very solid and crisp and of a fine nutty flavor.

\section{White Plume}

This is the earliest and most easily blanched, but does not keep well taken from the trenches. The plants grow rapidly and blanch easily during the summer months. Later in the fall the central stalks and leaves are of pure snowy whiteness even without earthing up.

\section{Boston Market}

For many years one of the most popular sorts in the markets of Boston. Instead of a single large heart it forms a number of smaller ones which are very white, and remarkably tender and crisp. The best variety for light soils.

\section{CUCUMBERS}

\section{Chicago or Westerfield Pickling}

A variety esteemed and grown extensively for the large pickling establishments:

\section{Improved Long Green}

Fruit long and slim, not surpassed in quality by any variety.

\section{Early Cluster}

Vines rigorous, producing the bulk of the crop near the root and in clusters.

\section{Green Prolific or Boston Pickling}

A favorite with pickle growers and commercial gardeners and good for table use.

\section{Early Frame or Short Green}

An excellent sort for table use and for pickling. Fruit straight, handsome, smaller at each end, bright green; flesh tender and crisp and makes fine pickles.

\section{Early White Spine}

One of the best sorts for table use. Vines vigorous, fruiting early and abundantly.

\section{SWEET CORN \\ Country Gentleman}

We have a stock of this excellent sweet corn that is exceptionally good. There is no sweet corn that compares with the Country Gentlemall for sweetness. It is the variety par excellence where quality is desired. Market gardeners who make a specialty of growing for hotels and high class restaurant trade use this as a main crop variety in preference to any other. For home use is will be found superior and it is very productive. The fact that it is a favorite variety with canners proves its merit.

\section{White Cob Cory}

This is an improvement over the Early Cory, as the cob is white, which gives it a finer appearance. It is as early as the Early Cory and of excellent quality.

\section{Mammoth White Cory}

The ears are twelve rowed, much larger than the old Cory, white cobbed, and covered with very large white grains of good quality.

\section{Early Minnesota}

One of the standard early sorts. Ready for market twe weeks later than Cory.

\section{Early Mammoth}

Closely resembles the Late Mammoth, but is a little smaller, and about two weeks earlier. of good size and quality.

\section{Stowell's Evergreen}

This standard main crop variety excels all other late sorts in sweetness and productiveness. It is more popular than any other for canning, for marketing and for the home garden. Great care has to 
be exercised in the selection of stock to grow seed from, as this variety has a tendency to deterioration and a shorter grain, which makes it less sugary and desirable.

\section{Golden Bantam Sweet Corn}

A very early sweet corn with golden yellow grain, very tender and of excellent quality. The ears are six to seven inches long and of the medium size found most suitable for the table. The flavor is exceptionally rich and delicious. Our stock has been very carefully selected. Height about four feet.

\section{LETTUCE}

\section{Black Seeded Simpson}

We have a fine strain of this lettuce carefully selected. This is the most popular loose-leaved sort.

\section{Early Curled Simpson White Seed}

Forms a close, compact mass of curly yellowish green leaves. Earlier than the head varieties.

\section{Grand Rapids Forcing}

Preferred by a great many to the Black Seeded Simpson, on account of being a tougher leaved lettuce.

\section{Buttercup}

A head lettuce of fine quality. Inside of head is waxy, crisp and delicious.

\section{Hanson}

Heads, very large from two to three pounds each; hearts quickly and stands the summer well; quality excellent.

\section{Oak Leaved}

Leaves light green, oak shaped, slightly curled; set close, having no coarse stems; of fine flavor and extreme tenderness.

\section{Denver Market}

This is a fine crisp, crimpled head variety.

\section{Brown Dutch}

This is a good variety. Makes a round head tinged with red.

\section{MUSK MELON}

\section{Rocky Ford}

This has become one of the most popular of small or crate melons and is shipped in large quantities from Colorado and Arizona. The vines are vigorous and productive. The fruits are oval, slightly ribbed, densely covered with fine netting. Flesh green, very sweet and highly flavored.

\section{Defender}

This is one of the best yellow fleshed sorts in some respects is far superior to any of this class. The fruit is medium sized, oval in shape, slightly ribbed, covered with gray netting. The flesh is firm, fine grained, rich, deep yellow, darker than that of the Osage and of higher flavor.

\section{Early Hackensack}

The fruits are nearly two weeks earlier than Hackensack, medium to large sized, nearly round or somewhat flattened, evenly and deeply ribbed and with very coarse netting. The skin is green, slightly tinged with yellow as the fruits mature. The flesh is green, a little coarse, but juicy and sweet.

\section{Burrell Gem}

The originator says: "The new Rocky Ford Melon with Golden Meat." This describes the melon fully, as in the outside appearance it looks just as the best types of green fleshed Gems, or Rocky Fords, do, but has orange flesh inside.

\section{Admiral Togo}

This is an orange fleshed netted Gem or Rocky Ford.

\section{The Osage}

Is of medium size, oval in form, dark green in color, somewhat netted and slightly ribbed. The flesh is extremely and uniformly thick, of firm texture, rich salmon in color; highly flavored and delicious to the rind. Cavity very small. It is a remarkable keeper and a good shipping melon.

\section{Jenny Lind}

Vines rather small but vigorous and productive. Fruits small, somewhat flattened, deeply ribbed and well netted. Flesh green and exceedingly sweet.

\section{Emerald Gem}

A very early melon of small to medium size. One of the very best for the home garden. Vines vigorous and productive. Fruits globular or slightly flattened, somewhat irregularly ribbed and very slightly netted.

\section{Hoodoo}

A new orange fleshed variety, ideal as a shipping melon and of the very finest quality. Vine vigorous, remarkably blight resisting and very productive. Fruits uniformly of medium size. Netting exceptionally fine and dense, extending practically over the entire surface.

\section{WATER MELON}

\section{Tom Watson Water Melon}

Originated near Augusta, Ga., a few years ago; very prolific-six carloads on ten acres often made; shape long; color dark, deep green no stripes; large-often times 50 to 60 pounds; two melons to the vine; no ends, no necks to rot; better shipper than Rattlesnake; tougher rind; flesh deep red; seeds white, smeared with yellow.

\section{Gypsy, or Georgia Rattlesnake}

One of the largest varities, and stands shipment long distances. Fruit cylindrical, square at the ends, smooth, distinctly striped and mottled light and dark green.

\section{Sweetheart}

This melon is early, large, handsome, heavy and productive. The shape is oval, and color mottled light to very light green. 


\section{Florida Favorite}

A very large, long melon, mottled dark green, with stripes of lighter shade.

\section{McIver's Wonderful Sugar}

Without a single exception this is the sweetest watermelon of all.

\section{Monte Cristo or Kleckley Sweets}

A splendid sort. Vine vigorous and productive; fruit of medium size; oval; color dark, mottled green in two shades, forming indistinct stripes.

\section{Peerless}

The old but extremely popular home market melon. There is none better nor a more handsome melon grown.

\section{ONION SEED}

\section{Large Red Wethersfield}

We have a very fine and select strain of this sort. Color is deep purplish red, flesh white moderately grained and very firm. YieIds an enormous amount per acre, and is one of the best winter keeping onions.

\section{Yellow Globe Danvers}

This fine onion is of large size. An early and abundant cropper. Bulbs very thick, flat or slightly convex bottoms, full oval top with small neck and rich brownish yellow skin.

\section{Southport Red Globe}

This is a fine keeper. Large size and considered one of the best red onions. Flesh is fine grained, very mild and tender.

\section{Early Flat Yellow Danvers}

A good variety, but not as round or quite as early as the Yellow GIobe Danvers.

\section{Prizetaker}

Grows to an immense size and for fall marketing is unexcelled. Although of such great size, it is very hardy and a fair winter keeper, as it ripens up hard and firm; very fine grained, and of mild, deli cate flavor. The outside skin is rich yellow while the flesn is white. To get the best results from this onion the seed is sown in beds and transplanted. It will, however, make a good crop if sown in the ordinary way.

\section{Philadelphia Silver Skin}

Very desirable for family use. Flavor mild and pleasant.

\section{White Barletta}

When matured the tops die down, leaving beautiful and perfect little bulbs. The color is pure white, flavor mild and delicate, perfectly adapted for pickling and table use.

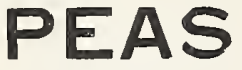

\section{Alaska}

Well known and extensively used, especially by canners. Very early and when carefully grown, uniform in ripening. Vine is strong and vigorous,
2 to $2 \frac{1}{2}$ feet high, of a peculiar light green color;

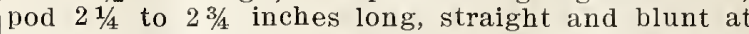
the end, and light in color. Is ready for picking 49 to 50 days from planting. Seed round, bIue, slightly pitted.

\section{First and Best}

Early, productive and hardy with a strong, vigorous vine, which is light in color and uniform in growth, 2 to $2 \frac{1}{2}$ feet in height and bearing straight pods $2 \frac{1}{2}$ to $23 / 4$ inches long, round light n color and blunt at the ends. Is fit for table use 50 to 52 days from planting. Seed round, rather small, and white in color.

\section{Telephone}

Vines and leaves large and coarse. Foilage light green in color. Height 40 to 50 inches, pods $4 \frac{1}{2}$ inches long, broad, pointed, medium green in color. Fit to pick 62 to 65 days from planting. Seed large, green, wrinkled.

\section{Pride of the Market}

Of fine growth and general appearance, both vine and pod, and closely resembles the Stratagem except that the vine is not quite so long and the pods are deeper green in color. The vine is 20 inches high, foliage dark green color. Pods are $3 \frac{1}{2}$ inches long, broad and dark in color. Fit for table use 61 days from planting. Seed bIue, slightly dented, large.

\section{Telegraph}

Closely resembling Telephone in all respects, except that the pods are a deeper shade of green, and the peas are of only fair quality, although the pods are of very fine appearance. Pods 4 to $4 \frac{1 / 2}{2}$ in. long, medium dark green, pointed. Fit to pick 65 days from planting. Seed, large, blue and round, dented.

\section{American Wonder}

Vigorous, productive vines, with luxuriant foliage, and producing the leaves on one side of the stalk, growing from 9 to 12 inches high. On account of its dwarf habit of growth it is very desirable for private garden use. Pods are light colored, straight, round, about $2 \frac{1}{2}$ inches long and bIunt at the end. Fit for picking 55 days from planting. Seed is wrinkled, green, medium in size and square at the ends.

\section{Abundance}

Vigorous in growth and productive, bearing pods in great abundance, although of medium size, and of excellent quality. Very similar in every respect to Horsford's Market Garden, except that it is about a week later, being fit for picking 71 days from planting. Pods are dark green, and blunt. Seed green, wrinkled, medium in size.

\section{Premium Gem}

Strong and vigorous, producing vines from 18 to 24 inches in height, dark foliage, bearing pods singly on both sides of the stalk beginning near the ground. Pods are almost straight $2 \frac{1}{2}$ to $2 \frac{3}{4}$ inches long, light in color and bIunt at the ends. Ready to pick 59 to 61 days from planting. Seed is green, wrinkled and medium in size.

\section{White Marrowfat}

Vines hardy, strong, vigorous and bearing broad thick leathery pods near the top of the vine, and containing peas of a poor quality. Height 45 to 50 
inches, foliage light green in color, pods 3 inches lollg, blunt and light green. Ready to pick 69 days from planting. Seed large, smooth, white.

\section{Dwarf Gray Sugar}

The o!d variety of the edible-podded sort, and is used in no other way. Grows about 2 feet high and is remarkable for its earliness. Pods are broad, flat and crooked and contains 5 to 6 peas. seed is brown and wrinkled.

\section{PARSLEY}

\section{Double Curled}

The standard sort for outdoor culture, also highly prized by market gardeners for the greenhouse.

\section{Plain}

Leaves flat, deeply cut but not curled; often preferred on account of the very dark green color as well as the hardiness of the plant and its superiority for flavoring. The curled sorts are more extensively used for garnishing.

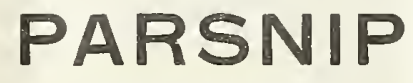

\section{Hollow Crown}

Roots long, white, smooth, tender, sugary and of most excellent flavor. Very hardy, and will keep through winter without protection.

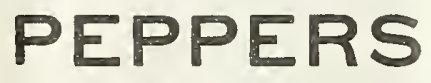

Long Red Cayenne

A loug, slim, pointed pod, and when ripe, of a bright red color. Extremely strong and pungent.

\section{Red Chili}

Used in the manufacture of pepper sauce.

\section{Large Bell or Bull Nose}

A very large sort of inverted bell shape, suitable for filling or for a mixed pickle. Flesh thick, hard and less pungent than most other sorts.

\section{Sweet Mountain}

Plants very vigorous and productive, growing upright, with moderately large leaves. Fruit very large, long, often 8 inches or more in length, by 2 inches in diameter.

\section{Ruby King}

An improved American sort, reaching the largest size, yet retaining the symmetrical shape of the smaller sorts.

\section{Golden Dawn}

In shape it resembles the popular Bell or Bull Nose pepper. It is of a most beautiful golden yellow color, maliing a very handsome appearance, both in growth and upon the table.

\section{PUMPKIN}

\section{Sugar or Pie}

A rather small, but handsome variety. Shape, round; skin deep orange colored; flesh fine grained, sweet-flavored; superior for pies.

\section{Connecticut Field}

The hardiest of all pumplxins; cultivated mainly for stock-feeding, producing enormous crops.

\section{Mammoth Potiron}

The flesh and skin are of a bright golden yellow color. Flesh fine grained and of excellent quality This enormous variety has been grown to weigh 200 pounds.

\section{RADISH}

\section{Scarlet Turnip, White Tipped Forcing}

An, early strain of the White Tipped variety, having a short leaf and suitable to plant in the green house.

\section{Early Scarlet Turnip}

The standard early turnip radish. Fine flavored and mild.

\section{Scarlet Olive}

Very tender and a beautiful color. Early.

\section{Early Scarlet Globe}

A desirable sort for hotbed forcing and outdoors, very early; flavor mild; crisp, juicy and tender; top small; will stand heat without becoming pithy.

\section{New Deep Scarlet Turnip}

This is a very bright colored searlet Turnip radish, very early and short leaf, well adapted to forcing under glass. Matures in fourteen to twenty-one days, and its appearance will sell it in any market.

\section{Crimson Giant Turnip, Turnip Rooted Forcing}

A variety extraoldinary in that, while growing to an unusually large size, it is always tender, crisp of mild flavor. It remains in perfect condition a remarkably long time, and unlike other forcing varities, does not become pithy even when twice their size in diameter.

\section{Golden Globe}

This variety is of quick growth, affording crisp and tender radishes even in the hottest climate and is extensively grown in the south.

\section{Early White Turnip Rooted}

A little flatter than the Scarlet Turnip and pure white in color.

\section{Half Long Deep Scarlet}

A variety half the length of Long Scarlet and of same form.

\section{French Breakfast}

Olive shaped scarlet, with white tip; crisp and tender

\section{White Strasburg, or Summer Hospital}

Large, showy, half long, white sort. Grows with great rapidity, sometimes producing a crop in six weeks. 


\section{Giant Stuttgart}

A summer variety. Grows to an immense size. White flesh, very crisp and tender. Of good flavor, and a good keeper.

\section{Chartier}

Decidedly distinct in appearance. The color at the top being crimson, running into pink about the middle and from thence downward it is a pure waxy white.

\section{Early Long Scarlet, Short Top}

This bright scarlet, small topped sort is about six inches long, is uniformly straight, smooth, brittle and crisp, and is a standard and excellent sort for private gardens or market use.

\section{White Icicle}

This handsome white variety is becoming very popular. It is similar to White Vienna but is not so long, is earlier and has a shorter leaf. We recommend it as a profitable, early variety where a long white sort is desired.

\section{Long White Vienna, or Lady Finger}

A very excellent white variety with long, very smooth white roots, which are crisp and tender. It comes into use shortly after Wood's Frame and is one of the most desirable of the white summer sorts.

\section{Rose or Scarlet China}

Roots cylindrical, or largest at the bottom, tapering abruptly to a small tap. Skin very smooth and of a bright rose color; flesh firm, crisp, tender and quite pungent.

\section{Long Black Spanish}

One of the latest as well as hardiest of the radishes; an excellent sort for winter use.

\section{White China or Celestial}

A comparatively new variety which is popular wherever known. The root is long, cylindrical, with beautiful white skin and flesh so white as to attract attention, even among the other white varieties. The flesh is very tender and of excellent quality.

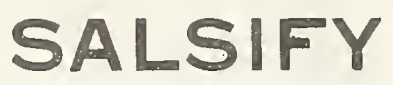

\section{(VEGETABLE OYSTER)}

The long white tapering root of salsify resembles a small parsnip, and when cooked is a good substitute for oysters, having a very similar fiavor.

\section{Large White}

The common variety; roots medium sized, smooth; flesh white.

\section{Mammoth Sandwich Island}

This is in every way superior to the Large White, being larger, stronger growing and less liable to branch. Invaluable to market gardeners.

\section{SPINACH}

\section{Savoy Leaved}

The earliest variety and one of the best to plant in autumn for early spring use. Plant of upright growth, with narrow pointed leaves which are curled like those of Savoy cabbage.

\section{Round Summer Broad Leaved}

This variety is generally preferred in the North for early spring sowing, and is the most yopular with our market gardeners.

\section{Prickly Winter}

A very hard variety and will withstand the severest weather with only a slight protection of leaves or straw.

\section{SQUASH}

\section{Giant Crook-Neck}

This strain is a great improvement on the old variety of Crook-neck. It is larger and better in every way.

\section{Mammoth White Bush}

This variety is a selection made from the Early White Bush; the improvement consists in size of the squashes it produces.

\section{Early White Bush or Patty-Pan}

Is earlier than any other variety of dwarf habit and very productive. Summer Squashes should always be used when young and tender, which can be determined by an impression of the nail.

\section{The Hubbard}

Cannot be too highly extolled as a Winter Squash; it boils smooth and dry, is of very rich quality, and keeps as solid as a rock. It is more poular with private growers than any other variety.

\section{TOMATO}

\section{Stone}

Large, smooth, solid, scarlet, highly recomminded.

\section{Livingston's Perfection}

Identical with Paragon.

\section{Earliana}

Vine similar in growth, maturing bulk of crop as early as Atlantic Prize, but the deep scarlet fruit is larger, distinctly smoother, solid and of very good quality. Early, smooth and of a large size it is a particularly profitable tomato for market gardeners.

\section{Livingston's Beauty}

Large, solid, smooth; purplish pink.

\section{Livingston's Favorite}

Bright red, smooth, of good size.

\section{Ponderosa}

A purplish pink tomato of largest size. Vine vigorous and very productive. Fruit very solid, fairly smooth and considered of very good quality, especially by those who prefer a tomato quite free from acid. 


\section{Yellow Pear}

Pear shaped; yellow.

\section{Strawberry or Husk Tomato}

Plants of low-spreading growth and immensely productive. The small yellow fruits are each enclosed in a husk. Of very sweet flavor, highly eśteemed for preserving or making pies.

\section{Red Pear-Shaped}

This is a leading favorite for preserves and also to make "tomato figs." The fruit is bright red, of true pear shape, and of rich distinct flavor.

\section{TURNIP}

\section{Extra Early White Milan Turnip}

The Purple Top Milan is one of the most popular turnips for spring sowing, but in this new sort we have a splendid extra early turnip in which the extreme earliness, small top and tap root of the Purple Top Milan is united with clear white skin and flesh.

\section{Early White Flat Dutch}

An excellent garden variety. The best for spring sowing.

\section{White Figg}

Belongs to the class of quick growing fall turnips, and for this purpose should be sown, in this latitude, between August 10 and 25 .

\section{Purple Top White Globe}

An early variety. Globe shaped; heavy cropper. In other respects similar to the Red Top Strap Leaf. A handsome looking bulb, and is rapidly taking the lead of all other varieties of early turnips for market garden purposes.

\section{Purple Top Strap Leaf}

Rapid grower and mild flavor, the most popular variety for early use, either for the table or stock.

\section{Cow Horn}

This variety is pure white except a little shade of green at the top, and is carrot-like in form, growing nearly half out of the ground, and slightly crooked.

\section{Sweet German}

This variety is very popular in many sections, notably so in the New England states.

\section{CLOVER SEED}

\section{(Common Red)}

\section{Iowa and Wisconsin Grown Seed}

Wisconsin is now producing the finest Clover Seed. Local conditions in Iowa for three years have not been favorable for the production of fancy or even choice seed.

When yol buy your seeds from us your run no risk. If not entirely satisfactory on receipt you may return them at our expense and money paid for them will be refunded.

PIEASE NOTE-Prices of Clover and Timothy are snbject to fluctuations of the market. Buy- er's should write for firm and lowest price before buying, which we quote by return mail. Then there is sure to be no misunderstanding.

\section{Mammoth Clover}

$50 \mathrm{c}$ per bushel higher than Common Red-same grades.

\section{Alfalfa Clover Seed}

Our seed is raised on non-irrigated land and is better adapted to this part of the country than seed from the irrigated parts.

The great bulk of American seed is grown under irrigation and does not possess that vitality in adjusting itself to normal conditions that seed does where grown under natural conditions. We purchase all our seed direct from the growers in southern central Nebraska and northern Kansas and know what we are getting; therefore you can rely upon seed you get from us being grown under natural conditions and of the best quality that can be produced.

\section{South Dakota Alfalfa}

The remarkable success which followed our sales of South Dakota grown alfalfa last year proves conclusively that their is something in the claim that alfalfa grown on the dry land of that arid region will stand our changeable climate, better than western or southern grown seed. We sold much of this seed last year all from recorded fields where it had been grown from 16 to 24 years and never failed, and where it was subject at times to 45 degrees below in winter and as high as 116 degrees of heat in summer. Every bushel we sold last year was from recorded fields and the results have been more than satisfactory. We will have in stock this year seed from the same localities. Prices on application.

\section{White Clover}

By $r$ ail, $50 \mathrm{c}$ per $1 \mathrm{~b}$

\section{(Crop Almost a Failure.}

\section{Alsike or Swedish Clover}

A very hardy clover Perennial. On rich, moist soils it yields an enormous quantity of hay or pasturage, but its greatest value is for sowing with other clovers and grasses, as it forms a thick bottom and greatly increases the yield of hay; cattle prefer it to any other forage. The heads are globular, fragrant and much liked by bees, which obtain a large amount of honey from them. Sow in spring or fall at the rate of six pounds per acre when used alone.

\section{Sweet Clover (Melilotus Alba) White Blossom}

Sweet Clover has been attracting attention during the last few years until the seed seems to be in greater demand. In fact the seed is very high again this year. A few of the reasons why the sweet clover crop is valuable are:

1. It grows readily on most all soils and locations.

2. It has the same sort of bacteria laden ncdules as alfalfa and innoculates a farm for that crop. If alfalfa does not do well on your farm try sweet clover first.

3. Sweet Clover brings land up rapidly to a high state of fertility and fits it not only for alfalfa but for crops of all kinds.

4. It can be pastured while alfalfa cannot, and stands pasturing better. even than red clover. 
5. Cattle and hogs both very soon acquire a taste for sweet clover and relish it and thrive on it.

6. At the Iowa Ex. station it outclassed red clover in its stability to carry more hogs and to furnish green pasture for a longer period.

\section{TIMOTHY}

\section{Choice Iowa Grown Timothy}

Our seed is absolutely pure, bright, beautiful seed; we take pride in our Timothy seed. Sow 12 lbs. per acre. Cut in bloom.

Market prices are so fluctuating we do not undel take to make firm prices beyond present stocks, which are at present sufficient under ordinary conditions to meet the requirements of our trade.

\section{BUCKWEAT}

Japanese Buckwheat

This is larger than the common variety.

\section{GERMAN MILLET \\ Northern Grown Millet} soil.

Best for rich land, but produces fine hay on poor

\section{Southern Grown Cultivated}

On good, rich soil, it will make a growth of 4 to 5 feet high, although the hay may seem coarse yet it is so tender that if cut at the right stage, which is when in full bloom, even the hogs will eat the cured hay quite greedily. A yield of 5 tons of hay per acre is nothing unusual. Sow 3 pecks per acre.

Nothing pays better for a stock raiser and dairy farmer than a few acres of Millet of some kind, for it is of the greatest feeding value and milk producing quality, and yields at least again as much of the most delicious hay per acre as timothy and clover. It should be sown regularly every year, and not merely as a catch crop. When spring is so unfavorable that other crops fail to grow, or when the season is so late and wet that other crops will not mature any more, then there is always the greatest demand for millet. Write for lowest prices stating amount wanted.

\section{Sorghum (Sugar Cane for Fodder)}

The greatest of all forage and fodder plants. It will yield two crops of fodder and a good fall pasture in one season. Roots deep into the sub-soil and stands drouths that often destroy other crops. As a rough provender it is unsurpassed. Sow 1 to 2 bushels per acre.

As a Pastme and Fodder Plant it beats everything. It is extremely profitable for this purpose as the cane can be cut and partly cured, and in this way yield from 15 to 20 tons of magnificent fodder to the acre. For fodder, cut as soon as the blossoms come out of the head. Leave for two or three days on the ground, and then put up in shocks of about one load each. It can be cut repeatedly and springs up quickly again.

\section{Kaffir Corn}

This is especially desirable for planting where the summers are hot and dry. The stout stalks grow stiffly erect from six to ten feet in height.
The stalks and blades cure into good fodder and are also desirable to furnish green forage during summer months. The seed is borne in a loose branching head ten to twelve inches in length at the top of the stalk. On good land Kaffir Corn will yield fifty bushels per acre. The seeds are esteemed for feeding to both stock and poultry.

\section{Mammoth Russian Sunflower}

Sunflower seed is one of the best egg producing foods for poultry. It can be sown any time before the middle of July. Plant in hills $3 \frac{1}{2}$ to 4 feet apart each way, or in drills. Six quarts will sow an acre. Seeds are the best of food for poultry, and is much cheaper to raise than corn. Price: Large pkt., 5c; 1 lb., 20c; 3 lbs., 55c. By freight, 10 lbs., $\$ 1.00 ; 1 \mathrm{bu}$. or $25 \mathrm{lbs} ., \$ 2.25$.

\section{COWPEAS}

Good cowpeas hay is fully as valuable a feed, pound for pound, as red clover hay, and very nearly equal in value to alfalfa or to wheat bran. The principle value of this hay lies in its high percentage of digestible protein, which is nearly four times that of timothy hay.

When grown for hay production cowpeas are nearly always broadcasted or put in with a grain drill any time from May 15 th to July 15th. The quantity of seed used to the acre ranges from one to one and a half bushels when drilled, broadcasting requiring from one and a quarter to two bushels. The quantity most commonly used and which gives the most general satisfaction when the seed is put in with a grain drill is decidedly superior to broadcasting. The practice of broadcasting on small grain stubble and plowing under the seed is still common; also that of putting in the seed or grain stubble with a disk drill without plowing. Both of these practices are rapidly being replaced by good preparation of the soil before seeding.

\section{Varieties}

The varieties more commonly used are Whippoorwill, New Era and Black.

We endeavor to keep a full stock up to 10 th of July. On application we will send you an interesting circular on this subject.

Write for prices on Cowpeas; we will make you delivered prices.

\section{SEED POTATOES \\ Red River Grown Seed Potatoes}

In order to secure the best possible yields, combined with the best quality, there is no crop grown that change in seed is so essential as in seed potatoes. There is a world of difference between Northern Red River grown potatoes and eastern or those grown along the lakes.

We ship our seed potatoes in the spring as soon as danger of freezing is over, so they will arrive in plenty of time for planting. All orders for potatoes are acknowledged as soon as received and forwarded the first day that we feel that it is safe to start them. When shipment is ordered otherwise, shipment is made at purchaser's risk and we assume no responsibility on account of freezing. We do not charge for bags, boxes or barrels. All potatoes are carefully packed and delivered to the railroad company in good order and condition, then our responsibility ceases.

Write for prices on Potatoes.

\section{Price List of all Varieties in Front Pages of Catalogue}




\section{Hammond's Slug Shot for Cabbage Worms}

\section{Hammond Slug Shot}

has never been known to fail in destroying leafeating insects. The composition is a dust strongly impregnated with fungicides, and in all the years of its use no harm has come to man, beast or fowl, through its use upon Potatoes, Currants, Cabbage, Roses, Bushes or Tree, for it kills or drives off larvae of all sorts, Slugs or Caterpillars. Put up in handy packages of $5 \mathrm{lb}$. each. Price delivered
to you by mail, local $40 \mathrm{c}$; 1 st zone or 50 miles,
$50 \mathrm{c} ; 2$ nd zone or 150 miles, $56 \mathrm{c}$. Full instructions with each package. If you save a bushel of potatoes you pay for the $5 \mathrm{lb}$. package.

Hammond's Slug Shot was made to kill potato bugs. It will kill currant worms, gooseberry worms and mildew. No lice on chickens where Slug Shot is used, or lice on calves and cows.

\section{CORN}

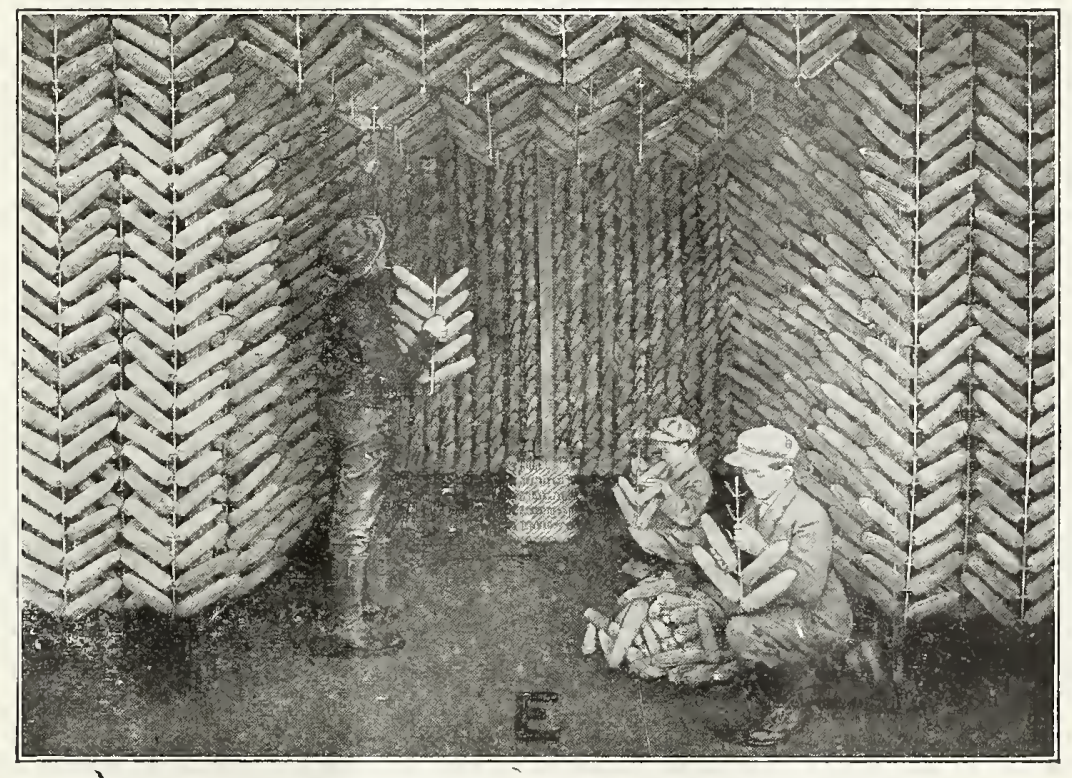

A Corner in Our Seed Curing Warehouse

\section{Good Seed Corn}

One of the most important questions before the farmer today is to get good seed corn, that is, a seed of standard variety, of high yield, early and sound maturity.

We offer you seed corn which we know answers these requirements. We have Funk's Yellow Dent and Reid's Yellow Dent in yellow, Boone County Special and Iowa Silver Mine in white. These varieties are selected from prize winning corn and we guarantee the purity of the stock. We do not offer a dozen or more varieties but confine ourselves to four that we can stand behind. All our Seed Corn is on the ear-when you buy it that way you can see that you are getting what you pay for. We offer no seed corn but what will germinate $95 \%$ or over. It will pay you to change your

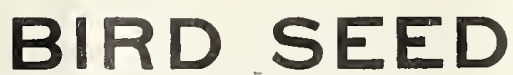

We are the only firm in this city who carry a fresh stock at all times of Hemp, Rape, Canary wholesale or retail quantities. Wre also keep a supply of Cuttle Bone. 


\section{LUTHER BURBANK'S SEED}

\section{Luther Burbank's Seeds}

The following list of flower and garden seeds comprise what we have in Luther Burbank's stock. Of course some of these are not Luther Burbank's productions, but they are seed from carefully selected stock by the Luther Burbank Co. and all bear the Luther Burbank trade mark seal on every package. These seeds are sold at $5 \mathrm{c}, 10 \mathrm{c}$ and $25 \mathrm{c}$ per packet. In addition we have a collection of one dozen packets for $\$ 1.00$. See note elsewhere.

\section{VEGETABLE SEEDS}

Corn-Rainbow

Giant Pepper

Tomato-Early

Beans- $\mathrm{Ky}$. Wonder

Beets-Blood Turnip

Cabbage - Jersey Wakefield

Cabbage-Flat Duteh

Carrot-French Forcing

Carrot-Half Long

\section{A. O. Daisy}

Beans-Crazy

Swiss Chard

Giant Calendula

Cassaba

Candytuft

Caliopsis-Tiger

Coreopsis Grandiflora

Coreopsis Golden Wave

Cosmos Lady Lenox

Centurea Cyanus

Centurea Marguerite

Delphinium
Celery-White Plume

Cucumber-White Spine

Lettuce-New York

Lettuce-Grand Rapids

Muskmelon — Rockyford

Watermelons-Kleckley Sweet

\section{A Luther Burbank Garden for $\$ 1.00$ \\ Burbank's Own Selection of His Own Seeds 12 Packages for $\$ 1.00$}

Enough for a garden of extraordinary character and beauty - a genuine Burbank garden. These are of highest quality.

An unique and acceptable present to your friends. Everyone enjoys rare and beautiful floweds. We will mail, postpaid, this unusual collection of Luther Burbank seeds to any part of the world for $\$ 1.00$.

$$
\begin{aligned}
& \text { Onions-Yellow Dan- } \\
& \text { vers } \\
& \text { Onions-White Portu- } \\
& \text { gal } \\
& \text { Parsley-Moss Curled } \\
& \text { Parsnips-Hollow - } \\
& \text { Crown - } \\
& \text { Pumpkin-Pie } \\
& \text { Peas-American Won- } \\
& \text { der }
\end{aligned}
$$

Peas-Telephone

Radish-Iong Scarlet

Radish-Scarlet Turnip W. T.

Squash-Hubbard

Squash-White Bush Scallop

Turnip-White Globe

Turnip-White Flat Dutch

\section{FLOWER SEEDS}

Dianthus Imperialis

Dimorpotheca Hybrids

Eschscholtzia Hunnemannia

Eschscholtzia Hybrids

Eschscholtzia Crimson

Eschscholtzia Fire Flame

Eschscholtzia Carminea

Euphorbia

Gaillardia

Godetia

Morning Glory
Nicotiana

Dwarf Nasturtium

Burbank Poppy

Horned Poppy

Evening Primrose

Salpiglossis

Scabiosa

Schizanthus

Shasta Daisy

Sweet Sunberry

L. S. Sweet Peas

Sunflower

Verbena

Giant Zinnia
L. R. R. H. Zinnia

Sweet Peas-Spencer Mixed

Wild Flower Garden

Phlox

Stock

Mignotte

Nasturtium-Tall Mixed

PansiesMixed

Alyssum

Asters-Mixed

Gourds-Mixed

\section{THE FISH SEPARATOR}

\section{A Eew}

Facts

Regarding

the

Fish

Grain

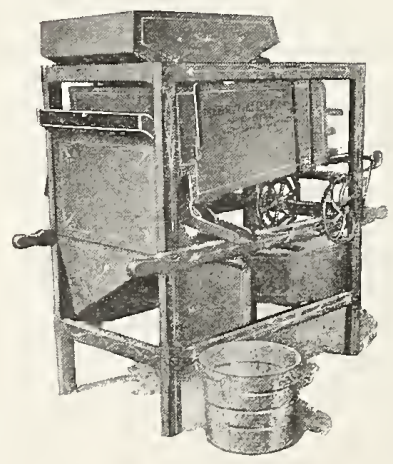

Separator
It runs by hand or engine power.

It is the most substantial and compact machine on the market, occupying a floor space $2 \times 4 \mathrm{ft}$. and will go through a door $2 \times 8$.

It is the only machine which grades all seeds perfectly and has the largest capacity of any seed grader on the market.

It makes a separation which is impossible for other machines to make.

It cannot clog or get out of order.

Our air is perfect for we have an automatic control.

It grades all seeds from blue grass to lima beans.

It separates sour dock and wild buckwheat from clover seed, which is impossible in other machines.

Send for descriptive circular and ask for prices. This is the Separator you want for general farm purposes.

We are in a position to make you a low price onthis Separator this year. 


\section{STANDARD HAND SEEDERS}

By close comparison in the field with the different varieties of seed, such as lettuce, radish, onion, beet, peas, etc., Standard Seeders have proved themselves equal and in many cases exceed all other similar tools in the distribution of seed evenly either in hill or drills.

The agitator on the shaft that runs through the hopper, stirs the seed and keeps a supply constantly fed to the revolving brush, which brush gently but positively feeds the seed through the opening in the bottom of the hopper. This is what we term our double agitator feed, which is not injurious to the seed and sure to feed. The revolving brush is entirely cased over, which protects the bristles and reduces any unnecessary wear on them.

The coverer is the swinging pattern that does its work well and adjusts itself to inequalities of the ground.
Standard Seeders also have less parts than any similar tools made. Fewer parts would mean less complication, less trouble and a more satisfactory tool.

Standard No. 11 Hill and Drill Seeder-This is the No. 9 tool set up as a hill and drill seeder and known as No. 11. Weight packed, 44 lbs. List price, $\$ 9.00$.

No. 9 Hill and Drill Seeder and Double Wheel Cultivator complete with all attachments, packed weight, 58 lbs. List price, $\$ 12.00$.

No. 10 Hill and Drill Seeder and Double Wheel Cultivator, packed with hoe blades only; weight 47 lbs. List price, $\$ 10.50$.

Seed planted with Standard Seeders is in perfect condition to cultivate to the best advantage after the plants are up.

\section{WHERE DO YOUR APFLES GO?}

The time has passed when good fruit can befcare you adopt. To obtain the better grade you produced with little or no attention to the grow- must spray systematically and Sherwin-Williams ing. Now fruits are good or bad, the extent of Insecticides will give satisfactory and economical either depending on the methods of culture and results.

Lime Sulphur Solution-For spraying mix onelthan paste form. Follow directions on can. One gallon to ten gallons water. Price for 50 gal. bbl., pound to 8 gallons of water.

$\$ 10.0 .0$; 5-gal can, per gal., $30 \mathrm{c} ; 1$-gal, can, each, $50 \mathrm{c} ; 1 / 2$ gal, can, each, $40 \mathrm{c} ; 1 / 4$ gal. can, each, $30 \mathrm{c}$; special prices on 10,15 and $20 \mathrm{bbl}$. lots.

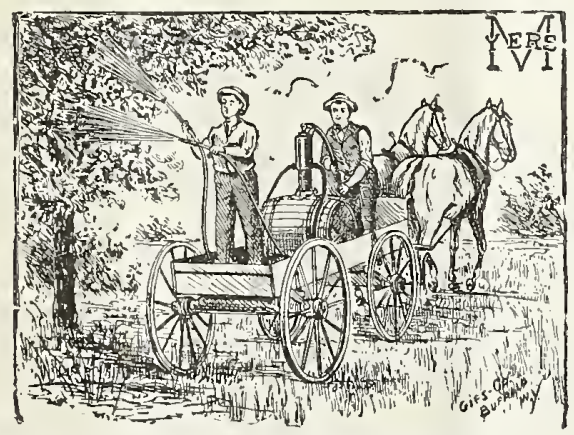

Arsenate of Lead-Sherwin-Williams' dry powdered; easier to handle and goes twice at far as paste form.

For wet spraying use 1 to 2 pounds to 50 gallons of water.

For dry dusting use just as it comes from the package.

Boldeaux Mixture--Sherwin-Willians' dry powder, easier to handle and much cheaper in the end

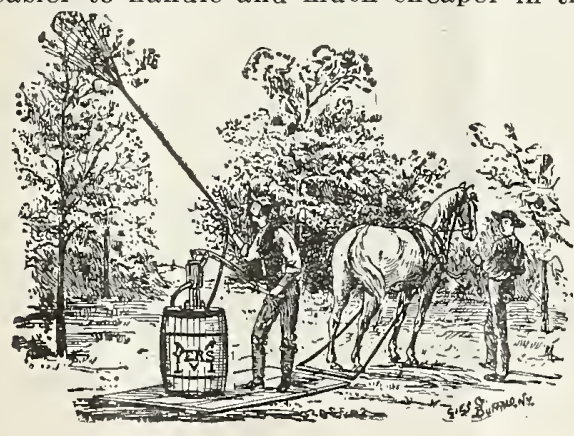

Paris Green-Ask for prices.

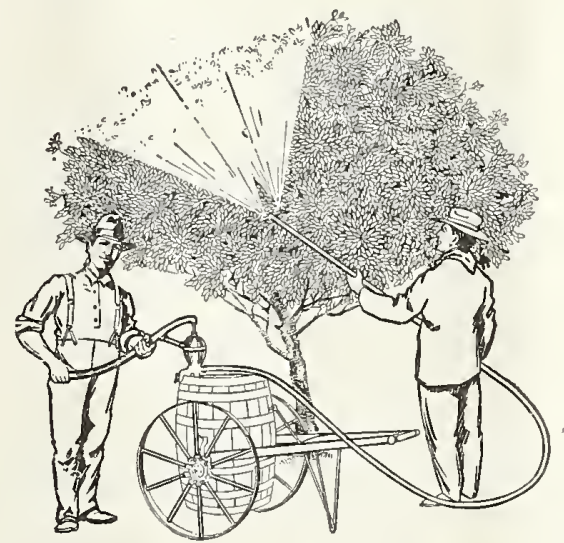

\section{More and Better Fruit}

No matter if you have one or a dozen trees, it doesn't pay to grow wormy or scarred fruit. You can have clean, well-colored fruit for your table or the market with but a slight effort and small expense. "Systematic spraying is the remedy an it pays a big dividend if you use good materials -. S-W Brand.

\section{Kill the Bugs-Increase Your Profits}

It is just as important to spray your vegetables as it is to cultivate them. Spraying will effectually control troublesome insects and fungus $d$ is eases, increasing your yield and the quality. Spray them with Sherwin-Williams Insecticides and Fungicides. 


\section{POULTRY SUPPLIES}

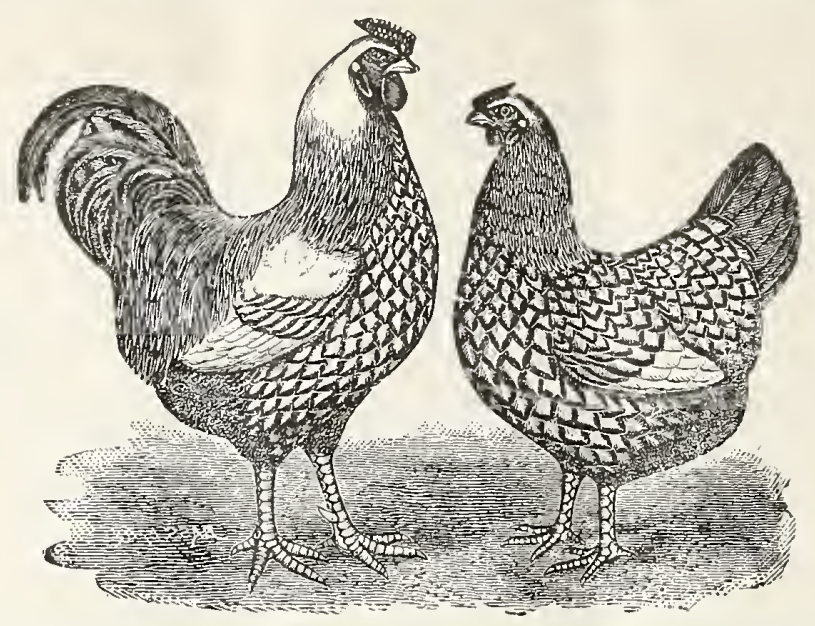

\section{STANDARD CYPHERS INCUBATORS}

\section{Hatch Strong, Vigorous Chicks and Lots of Them}

Poultry Raising for profit is no longer a "pin money" affair. Today it exists in one of three forms - as an important branch of farm work, or as a regnlar business, or as a money-making side line for the villager, the suburbanite or city dweller.

In whichever class you may be, Reader, we claim that you should "mean business" - that you should have the right kind of tools with which to do your work, because your success is going to depend in large measnre on the equipment you provide, and especially on your choice of incubators.

Buying an incubator is different from buying any other article in common nse. A farm wagon, a piece of household furniture or a jack knife, if of "cheap" make and inferior quality may answer the purpose for awhile and should last some time, but with an incubator (or a brooder) it is different-decidedly so.

And the reasons are plain. An incubator deals with the life principle! It must be relied on to do the delicate work of producing a living organism - a complete chick or duckling in perfect health, with all the vitality nature requires.

This matter of "vitality" in chicks is of the very highest importance. Here lies the Secret of Success, or a hidden rock upon which an otherwise well-planned poultry venture will meet with failure and heavy losses.

It is not alone the question of "how many" chicks, but also of HOW GOOD- of how strong, vigorous and healthy they are-how well hatched.

The hen knows how to produce the right kind of chicks. Nature has taken care of this-but it is the regrettable truth that vast numbers of incubator chicks are hatched every season which stand no show whatever of living to market age, on account of the flimsy, ill-constructed "boxes" in which they are "coaxed" into life. An incubator, to do its work right, must meet all of nature's requirements-it must not stop half way.

We could easily fill this catalogue with report from pleased and satisfied Cyphers Company customers, treating on this one point alone-of the ease with which they are able to hatch large per- centages of big, vitally strong and perfectly healthy chicks and ducklings in the Standard Cyphers.

Thousands of breeders-the most successful in all the country-have been hatching their most valuable eggs in the Cyphers year after yearstaking their very business existence on the results secured. It is incredible that they would do this if they did not absolutely know that the Cyphers is the best and most reliable hatcher to be obtained.

\section{Do Not Waste Time and Money on Poor Incubators}

Poor hatches mean small profits-or none at all. It is not the first fifty chicks you hatch out of each one hundred fertile eggs that will give you your profits-it is the number of good, healthy, vigorous chicks above fifty that must be relied on to make your poultry work a success.

Any well-made, high-grade incubator should last and do excellent work for at least tell years. To learn the actual cost therefore, that must result from the continued use of inferior, low-grade hatchers, you will need to multiply the "cheap" incubator losses by ten-yes, by more than ten, because flimsily-built machines will go entirely out of service within one to three years.

As manufacturers of high-class goods-of incubators, brooders and general poultry supplies, a ery one of which is guaranteed to do satisfactory work, we believe we are justified-that it is a part of our dinty to warn intending purchasers not to risk the success of their poultry ventures, small or 'arge, by the use of "cheap" incubators or worthless, death-trap brooders. And we regret to say that such articles are on sale-plenty of them.

If you are going to use an incubator at all, buy a good one-the best to be had. If you decide that you would like to own a Cyphers, we urge you to buy it first-not after you have tried some "cheap" machine and met with discouraging losses. When you buy one cheap incubator and discard that and buy another that is no better, you are overpaying the Cyphers price, without getting Cyphers results and satisfaction. Thousands have made that mistake-and have told us o.

Far too many poultry raisers are trying hard 
to get ahead by the use of poor equipment. To men and women in that position we can say only: Do not continue to worry along, fighting against heavy odds. If you own a type of incubator that is not turning out plenty of chicks-the kind "with the kick in them," the kind that grow rapidly right from the hour they are hatched-buy a Cyphers, any size you like, and test it one season alongside of the other kind. For you to do this will mean a great deal more to you than it can possibly mean to us.

\section{Cyphers Standard Incubators}

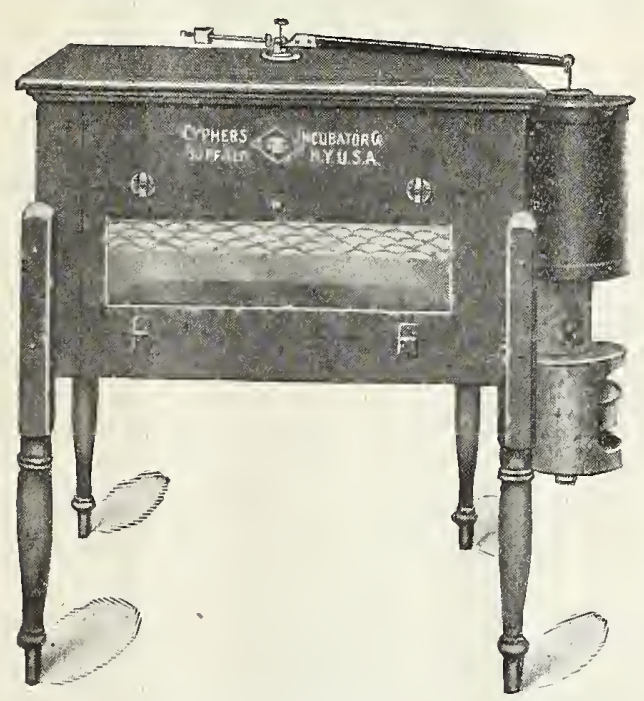

No. 1

144-Egg Capacity

\section{PIRTCE IIST OF STANDARD CYPHERS INCUBATORS}

Fire Proof-Insurable

No. 0 Incubator-Capacity about 70 Hen Eggs No. 1 In Eggs

No. 2 Inc1 about 144

Hen $\$ 15.00$ Eggs

No. 3 Incubator-Capacity, about 390 Hen Eggs

We supply án X-Ray Tester, a tested Standard Cyphers Incubator Thermometer, and our booklet, "Direction for Operating and Hints to Aid the Operator," packed in every incubator.

\section{INCUBATORS ARE BETTER AND CHEAPER THAN HENS}

Let us compare the use of a first-class incubator with the work of hens for hatching purposes. Of course on big poultry plants-either chicken or duck ranches - hen hatching is out of the question, because enough broody hens to do the work could not be secured at the right season of the year. But how about the use of incubators by farmers, villagers, etc?

We state on a thorough knowledge of the subject that if the best results-if the highest prices and largest profits are to be secured by the use of one, two, three or half a dozen incubators owned and operated by the farmer, his wife, son or daughter, or by anyone else who is conducting a small or moderate-sized poultry business, the hen should be used only for the production of fertile eggs-in which work she has a monopoly and is indispensable.

As is well known, the usual number of eggs entrusted to a broody hen is thirteen. At this rate it will require exactly thirty hens to take care of the number of eggs that one No. 3 Cyphers Incubator holds-390. In the first place, to get hold of thirty broody hens is practically impossible in December, January or February, except in warm climates, and to obtain this number would be a difficult matter even in March and April-for the average poultry raiser.

Then there is the labor, losses and inconvenience of caring for thirty "sitters" - in feeding and watering them, in letting them off the nests and seeing to it that they go back on the right nests, in keeping them from fighting and from breaking one another's eggs, in dusting them for lice, in cleaning the soiled eggs and removing the broken ones, in replacing sick hens and in attending to a dozen other annoying things that are certain to arisenot to mention the out-of-the-way place or places where this work is to be performed.

But with a first-class incubator all this work and worry is not merely "reduced to a minimum" -it does not exist. Positively, ten minutes in the morning and five minutes at night will give a $\mathrm{Cy}$ phers Incubator (any size, No. 0, No. 1, No. 2 or No. 3) all the care and attention it requires-ten minutes in the morning for turning the eggs, filling the lamp and trimming the wick, and five minutes at night to visit the machine, air or turn the eggs and satisfy yourself that everything is in good running order.

A well-ventilated house cellar or ordinary basement is still the best place in which to operate one, two or half a dozen Incubators, provided the machines are fire-proofed and insurable. The next best place usually available is a living room-an unoccupied room preferred, though many Cyphers Incubators are run with complete success in rooms used daily by the owners. Attending to an incubator-or two or three incubators-right in the house, is a very different matter from having to face all kinds of weather in looking after thirty or more sitting hens in outbuildings located some distance from the dwelling. This difference applies with special force if women do the work.

That a Cyphers Incubator will do better hatching, season in and season out, than can be done with hens, and that the use of Cyphers Incubators is far more satisfactory than the hen-method, has been testified to by thousands of our customers. Today many of these people would retire from the poultry business or would stop raising chickens in profitable numbers if they were compelled to give up their Cyphers Incubators and Brooders and go back to hatching and rearing with hens.

\section{Superior Incubators}

\section{HOT WATER VERSU'S HOT AIR}

No doubt there still are many prospective buyers of incubators who believe that hot water is a better or safer "heating element" for an incubator than is hot air. To meet this demand Cyphers Incubator Company now manufacturers, in two sizes, the strictly-high-class, copper-tank, woodencase, double-wall, self-ventilating and self-regulating Superior Incubators. These handsome and well-built machines are warranted by us to be just as represented and, nothwithstanding low prices, we positively guarantee them to do uniformly good work when operated according to directions.

Price of small-size Superior Incubator, capacity, 65 eggs, complete. (Shipping weight, 43 lbs.)

Price of large-size Superior Incubator, cacity, 130 eggs; complete (Shipping weight, $68 \mathrm{lbs}$ )

\section{Columbia Hot-Air Incubators} Columbia Hot-Air Incubators are made in two
sizes. The smaller size holds 140 average-sized 
hen eggs, and the larger machine holds 250 averaged-sized eggs. These machines are warranted to hatch duck eggs as well as hen eggs, having ample range of ventilation.

The picture shown herewith, shows the Columbias just as they are-attractive in appearance, substantial in construction and built by experienced, painstaking workmen out of first-slass materials. As is true of the Cyphers Company HotWater Superior Incubators, so also with these larger capacity Hot-Air Columbias, there is nothing "cheap looking" or crude about them. They look "every inch an incubator" and represent better value for the money than can be obtained in any other popular-priced "hatching machine" on the market.

The cases of the Columbia Incubators, except the fronts and bottoms, are of three-ply, veneered wood, the middle layer running crosswise of the other two, and the three thicknesses are solidly cemented (not glued) so they cannot warp, crack or split under the action of heat and moisture. The fronts, including the door frame, are of oneinch-thick selected white pine and the bottoms also are of pine. These all-wood cases are far better non-conductors of heat and cold than metal cases and they make a much handsomer incubator.

Both sizes of Columbias are equipped with regular Cyphers zinc-and-steel, toggle-joint standard regulating device, the same exactly as has been used on Cyphers Incubators for years with worldwide success. With reasonable care entire regulating device will last a life-time and continue to do its work. Every part is expertly made by longexperienced workmen in the Cyphers Company factory, using special machinery. Brass is used at all points where iron rust would interfere with accuracy and long life. The value and reliability of the Standard Cyphers regulator for incubator use are far above the ether-disc regulators usually furnished in popular-priced machines.

Columbia Incubators are both self-ventilating and self-regulating and when operated under normal atmospheric conditions they do not require supplied moisture. Please read the plainly worded guarantee.

\section{Prices}

Small-size Columbia Incubator, capacity 140 eggis, complete

(Shipping weight, 83 lbs.)

Large-size Columbia Incubator, capacity 250

eggs, complete

(Shipping weight, 114 lbs.)

\section{MANUFACTURERS GUARANTEE}

\section{Under Which Superior and Columbia Incubators are Sold}

That they are expertly built, using only firstclass materials and are attractive and durable in finish.

That with proper care they will last for years and continue to do the work required of them.

That they are self-regulating and self-ventilating and that when operated under normal atmospheric conditions they do not need supplied moisture.

That the chicks or ducklings, hatched in these self-ventilating machines, if well-fertilized eggs are used, will be large, fluffy and vigorous.

That when operated according to our printed directions, in any suitable place, these machines (both styles, all sizes, will do better hatching than any other make or makes of incubators on the world's markets that sell at as low prices as are charged by us in our catalogues and other printed matter for these machines.

CYPHERS INCUBATOR COMPANY.

\section{Cyphers Outdoor Brooders}

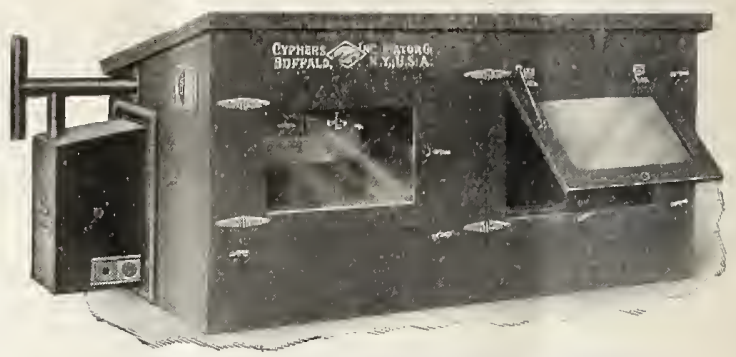

Cyphers Style B Outdoor Brooder

Fire Proof-Insurable.

Three-apartment, Combination Outdoor Brooder and Colony Roosting Coop. Self-ventilating and self-regulating. Built throughout of seveneighths inch thick lumber. Floors of hover and exercising apartments on same level. Large, single-pane, $12 \times 18$-inch windows with substantial frames. Double doors to exercising apartment for ready cleaning, and wire-protected for summer ventilation.

Style B Brooder is practically automatic in operation. It is both self-ventilating and self-regulating and takes care of itself, day or night, like a Standard Cyphers Incubator. The chicks entrusted to it require attention only as often as they need to be fed or watered.

Price-Cyphers Company Style B Out-door, selfRegulating, Self-Ventilating, Three-Apartment Combination Brooder and Colony Roosting Coop, equipped with Adaptable Hover, complete, $\$ 18.50$

Weight, safely crated, about $200 \mathrm{lbs}$.

The Cyphers Style A Outdoor Brooder is recommended for use of poultry raisers who feel that they do not wish to invest in the larger-sized and higher-priced three-apartment outdoor brooders.

Price-Cyphers Company Style A Outdoor, selfRegulating, Self-Ventilating, Two-Apartment Combination Brooder and Colony Roosting Coop, equipped with Adaptable Hover, complete, \$14.50.

Weight, safely crated, about 135 lbs.

\section{Cyphers Adaptable Brooding Hover}

\section{Can be Used Almost Anywhere}

This brooding device is called "Adaptable" because of the many practical ways in which it can be utilized by poultry raisers. As before stated, it is used in every style and size of Standard Cyphers Oil-Heated Brooders; it is also used with uniform success in one of the several long brooding houses on the Cyphers Company's fifty-acre poultry farm, Buffalo, N. Y., and it can be used with good results in other makes of brooders, provided the cases are not less than $2 \frac{1}{2} \times 3$ feet in floor space and 24 inches high; also as individual brooding devices in home-made cases, consisting of large dry goods boxes, organ or piano boxes; also in roosting coops; in colony houses and other portable poultry houses; also in connection with any ordinary hen house, closed shed or other outbuilding where a space can be partitioned or wired off for the chicks.

Cyphers Company Self-Regulating, Self-Ventilating Adaptable Hover, complete with Standard Cyphers Regulator and Tested Brooder Thermometer, safely boxed, $\$ 9.00$.

Weight, boxed for shipment, $38 \mathrm{lbs}$. 


\section{International Sanitary Hover}

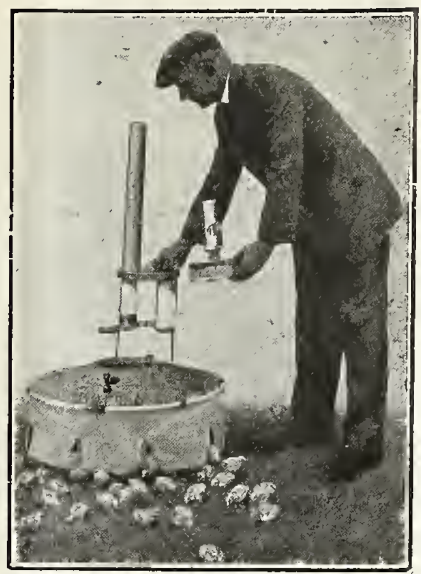

No crowding or smothering of chicks-no kneeling to get at the lamp. The International is portable, fire proof and vermin proof. Price

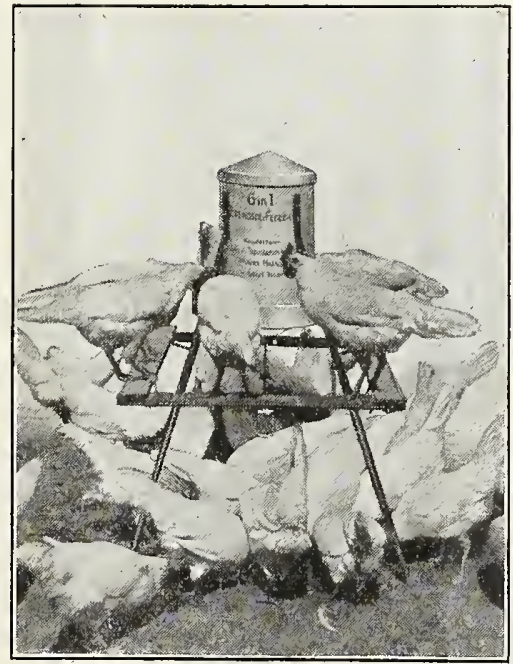

International 6 In 1 Exerciser and Feeder

Separate compartments supply Grain, Grit, Charcoal, Oyster Shell, Beef Scrap and Dry Mash.

The swinging pendulum drops the grain and the metal con scatters it-forcing the chickens to run after it. It eliminates all other feeding devices.

Price, complete

$\$ 3.75$

\section{Cyphers' Poultry Remedies}

\section{Cyphers Brand Nodi Charcoal}

Nodi Charcoal is useful as a blood purifier and disease preventive. It is one of the best remedies for sour crop, diarrhoea and other similar digestive troubles. That is why we call it "Nodi Charcoal"-no diarrhoea where this charcoal is used.

Prices of Nodi Charcoal: 2-1b. cartons (not mailable) each, 10c; 50-1b. sacks, each, $\$ 1.25$; two 50-1b. sacks, $\$ 2.25$. (By freight or express.)

\section{Napcreol Disinfectant}

Cyphers Napcreol is a highly-concentrated preparation which can be made ready for immediate use by simply mixing with required amount of water. Is highly valuable for the disinfection of incubators, brooders, poultry houses, stables, dog kennels, toilets, sinks, or any place where a germicide and deodorant is needed.

One gallon of Napcreol makes 50 gallons of disinfectant of sufficient strength to do the work

Prices: 1-qt. cans, 50c; half gal.-cans, $85 \mathrm{c}$; 1-gal. cans, $\$ 1.50$; parcel post weights: 1-qt. can, 4 lbs.; half-gal. can, 6 lbs.; 1-gal. can, 11 lbs.

\section{Cyphers Lice Powder}

Kills Body Lice on Chicks and Fowls-Easily Applied from Our Perforated "Shaker Boxes" in Which it is Sold.

A general complaint often heard among poultry keepers was that most of the lice powders on sale did not kill the insects, but only drove them from one place to another on the body of chick or fowl; then as soon as the powder lost its strength the lice would return to their favorite feeding spots and the injury was as great as ever.

Price of Cyphers Lice Powder: 5-oz. package, (trial size) 10c; postpaid, $15 \mathrm{c} ; 15-\mathrm{oz}$. box, 25c; postpaid, 40c; 48-oz. box (by express at customer's expense), 50c; 100-oz. package (by express at customer's expense), $\$ 1.00$.

\section{Cyphers Roup Remedy-Guaranteed}

A Complete Cure Guaranteed, or Money will be Refunded-Used in the Drinking Water

Cyphers Roup Remedy is the best remedy for Roup in all forms. It is thoroughly reliable and always uniform in quality and strength. Prevents and cures common colds, and for the cure of canker is without an equal.

One small-size package will make 25 gallons of roup medicine.

Prices: Small-size package, 25c, postpaid; mediun-size, $50 \mathrm{c}$, postpaid; large-size, $\$ 1.00$ postpaid.

\section{CYPHERS REMEDY NO. 4 FOR CHICK DIARRHOEA}

Remedy No. 4-For all diarrhoeas of poultry. It is the most reliable cure for cholera, and when used in the drinking water will cure the most obstinate cases. Valuable for diarrhoea in small chicks, especially when accompanied by a watery or a bloody discharge.

Prices: Single vials, in strong, specially prepared mailing tubes, $25 \mathrm{c}$ each; postpaid, $27 \mathrm{c}$ each.

\section{Crys-Co Grit and Shell Producer ITS ECONOMICAL FEATURES}

Containing $99 \%$ Pure Carbonate of Lime, it makes hard eggshells, increasing the hen's laying power. The fine for little chicks builds up the bones and makes fine feathers and is excellent for pigeons. The $1 \%$ flinty matter grinds the food so necessary for the chicken's digestion.

\section{Poultry Food and Grit}

\section{MICA CRYSTAL GRIT}

Hens having no teeth should be kept constantly supplied with some sharp material to grind and masticate their food. Mica Crystal Grit is not only sharp and hard, but its properties are such that it acts as a tonic and contributes largely to the health and productive power of the fowl. We 
have both hen, pigeon and chick size. State which is wanted. Price, $100-1 \mathrm{~b}$. sack, $\$ 1.00$.

\section{CRUSHEI) OR GRANULATED BONE}

Supplies the lime for shells and other ingredients necessary in the composition of eggs. Scatter about the poultry yard. 5 lbs., 25c; 100 lbs., $\$ 3.25$.

\section{FINE BONE MEAT,}

Excellent to aid in increasing egg production, and a splendid feed for young chicks. Should be fed wet, mixed with corn meal or bran. 5 lbs., $25 \mathrm{c} ; 50$ lbs., $\$ 1.75 ; 100$ lbs., $\$ 3.25$.

\section{RARVA MEAT MEAT,}

A valuable preparation for mixing with wet feed, supplying nitrogenous and fatty ingredients, especially in winter and spring. One lb., 10e; 4 lbs., $25 \mathrm{c} ; 100$ lbs., $\$ 4.50$. Subject to market changes.

\section{Crushed Oyster Shell}

The most frequent cause of hens not laying is the absence in the food of carbonate of lime. As crushed oyster shell is practically pure carbonate of lime, it supplies, when fed to poultry, the most essential element, and greatly aids in the formation of the egg.

\section{ADVANTAGES GAINED BY THE ISE OF OYSTER SHELT}

It prevents cholera; it keeps the $p$ o $u$ l t $r \mathrm{y}$ healthy; it makes hens lay an egg a day; it prevents soft shell eggs; it prevents hens eating their eggs; it makes the egg shell strong enough to carry without breaking; it contains many essential components of the egg. When you buy $100 \mathrm{lbs}$. of our Crushed Oyster Shells, you get $100 \mathrm{lbs}$. of shells, not 15 to $20 \mathrm{lbs}$. of dust and dirt mixed in as our brand is especially cleaned. To get best results in poultry raising, the use of something of this kind is positively necessary. Every poultry house or yard should have a pan or trough full, so that the fowls can have access to them at all times. Put up in 100-1b. bags. Our price, bags included, $85 \mathrm{c}$.

\section{BLOOD MEAL}

Single 1b., 5c; 5 lbs., 25c; 100 lbs., $\$ 4.00$.

\section{Unmixed Grains}

Prices named are those in effect on issuing of this catalogue. Subject to market change.

Wheat, price $100 \mathrm{lbs}$.

Prices per $100 \mathrm{lbs}$.

Corn, price 100 lbs..

Buckwheat, price $100 \mathrm{lbs}$

Hemp, price 100 lbs.

Chicken millet, price 100 lbs.

Hog Millet, price 100 lbs..

Canada Peas, price 100 lbs.

Sunflower, price 100 lbs.

$\$$

5 prevents all possibility of rusting or breaking off

\section{Cyphers Chick Food}

A Complete Food for Young Chicks up to Sir Weeks of Age, No Other Grain Being

Required or Advisable Ration

To obtain best results in raising chicks, good equipment and proper care are not enough-the food that you give them must be right in: substance, in "food values," in actual nourishment and also must be correct in proportions so that digestion and assimilation may be easy and complete. In compounding Cyphers Chick Food the protein or flesh and muscle-forming elements are maintained high; in fats and carbohydrates or heat and fat-forming elements are reduced to their proper proportion, and the ash or mineral elements are in sufficient amount to supply the needs of the rapidly-growing chick.

Prices: F. O. B. Muscatine, 100-1b. bag, $\$ 2.75$. Subject to market changes.

\section{Cyphers Scratching Food}

A Balanced-Ration, Cracked and Whole-Grain Mixture That Affords Variety, Insures Exercise, Maintains Health and Promotes Liberal Fgg-Yield

Exercise is absolutely necessary to promote digestion, maintain health, insure a continuous egg-yield and produce fertile eggs. Remember, that breeding fowls cannot be kept vigorous and strong by any method that does not reruire exercise, and plenty of it. A good scratching food fills one of the most important needs of the poultry raiser, if properly prepared.

Prices: F. O. B. Muscatine, 100-1b. bag, $\$ 2.65$. Subject to market changes.

\section{Cyphers Full-Nest Egg Food}

Full-Nest Egg Food is not only an egg-producer, but it is also a standard condition powder for all ages of poultry. Full-Nest Hgg Food will help your birds through their molt, make the feathers develop normally, and indnce a high state of perfection in plumage. Hence begin laying sooner after molting where this egg food is used. Prices. 42-oz. package, (not mailable) 25c; $25-$ 1). pail, $\$ 2.00$.

\section{Drinking Founts, Grit Boxes, Leg Bands, Etc.}

\section{SQUARE DROP-BOTTOM DRINKING FOUNTS}

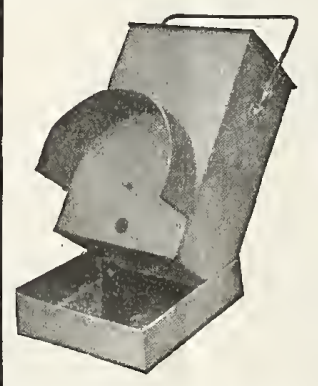

These drop-bottom drinking founts are new; they are made of No. 28 gauge galvanized steel. The bottom can be swung open with one hand as it is secured by one spring in the front, while most founts have a spring on each side and therefore require both hands to open them, which is even then done with more ore less trouble. The rod which extends through the hinge of the drop bottom is made of solid brass, which his hinge will preserve the life of the fountain.

Two quarts, $50 \mathrm{c} ; 1$ gal., $65 \mathrm{c} ; 2$ gal., $85 \mathrm{c}$.

\section{ROUND BOTTOM GRIT AND SHELL BOX}

Most grit and shell boxes have square bottoms, while this grit and shell box has a round bottom, which prevents the fine particles of shell and grit clogging the corners.

Can be hung on wall.

Compartment

Compartment $60 \mathrm{c}$

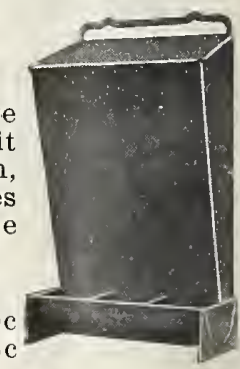




\section{CELLULOID SPIRAI LEG BANS}

provide instant identification of birds without handling, as far as you can distinguish color. They are as easily applied and removed from the bird's leg as a key from a key ring.

The band is light and durable and made in eight bright, fast colors, as follows: Red, Light Blue, Dark Blue, Pink, Black, Yellow, White, and Green. These bands are also made in four different sizes, Nos. $0,1,2$, and 3 . Every poultryman should have on hand at all times a supply of bands in assorted colors and sizes which will enable him to mark his birds so he can tell at a glance the ages, months hatched, matings, best layers, etc.

\section{Prices, Postpaid}

Size No. For Price Doz. 100

0 Chicks and Pigeons....\$0.15 \$0.85

1 Leghorns ...................... .20 1.00

2 Rocks and Orpingtons $.20 \quad 1.00$

3 Heavier Breeds, Turkkeys, Geese, and Ducks

$.20 \quad 1.00$

1,000

$\$ 7.50$

8.00

8.00

8.00

Be sure to state size and colors wanted.

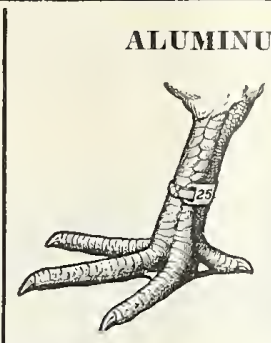

this numbered band.

can be adjusted to fit the leg of any size fowl. It locks with a double clamp, fits the leg perfectly, and, once on, stays until you remove it. They are sold in sets and numbered consecutively. The numbers ale always clear and distinct. Trap-nesters and show bird breeders will readily recognize the value of

Prices, Postpaid

Sets Numbered

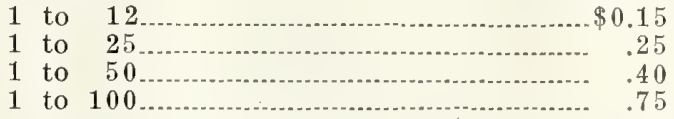

Price Per Set

Otis \& Mol's Top-Fill Founts, Trough and Hopper Feeders for chicks, Chick Waterers, Poultry Punches, and Egg Packages for shipping by parcel post.

Write for Cyphers Incubator Catalogue and Poultry Book, it's free! This book of over 200 pages contains much valuable information for poultry raisers.

\section{JAHNKE'S VERMIN TRAP ROOST}

A Ponlty Roost that Catches all the Mites, Spiders, Lice, Bedbugs, and all Other Bloodsncking Lice from the Fowls that Roost on It.

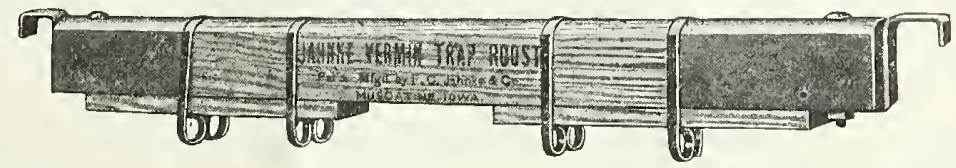

Neat, Clean, Light, Handy, Loose, Sanitary, Movable, Durable

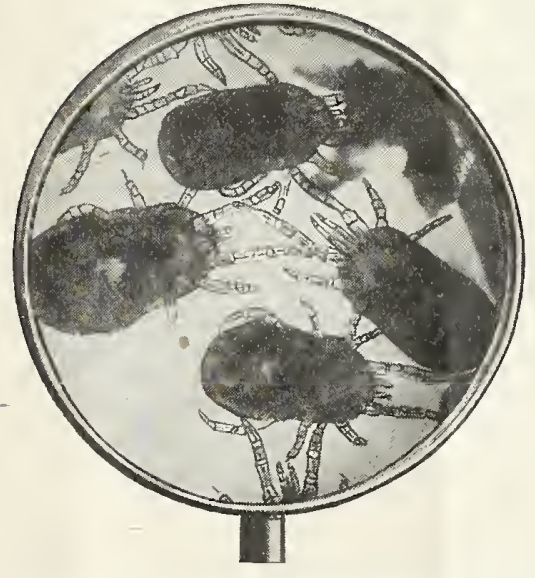

Mites Enlarged by a Powerful Magnifying Lens This picture was taken by J. B. Southall of Fairport, Iowa, with a photo micrograph.

These are the Fellows that crawl all over you every time you go into the hen house.

These are the Fellows that take the big end of your poultry profits by decreasing the egg production.

These are the Fellows that make your setting hens leave the nest.
These are the Fellows that kill your little chickens.

These are the Fellows that suck the very life blood of the fowls every night.

These are the Fellows that make every chicken weigh from one-half pound to a pound less when you come to sell it.

These are the Fellows that drive your chickens from the hen house to roost in the trees and on the fences, in order to escape their nighly torment.

These are the Fellows that are on your chickens and in your hen house now stealing your profits, and the only way you will ever get rid of them is to let your fowls roost on Jahnke's Vermin Trap Roosts.

\section{Price List for Single Roost Bar}

The price list given below is for one Single Vermin Trap Roost Bar, and you should order enough bars of the length you want to accommodate your flock.

1 Vermin Trap Roost Bar 4 feet 8 lowls.. $\$ 0.40$ 1 Vermin Trap Roost Bar 5 feet 10 fowls.- .50 1 Vermin Trap Roost Bar 6 feet 12 fowls. .60 1 Vermin Trap Roost Bar 7 feet 14 fowls. .70 1 Vermin Trap Roost Bar 8 feet 16 fowls. .80 1 Vermill Trap Roost Bar 9 feet 18 fowls.. .90 1 Vermin Trap Roost Bar 10 feet 20 fowls.. 1.00 


\section{The Vermin Trap Roosts in Use}

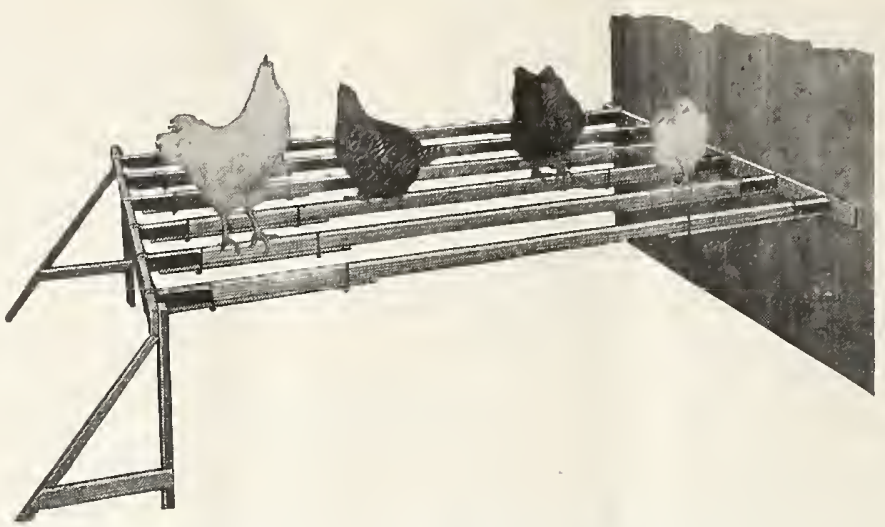

A Bucket of Hot Water and One Sweep of a Brushlold boy can empty the traps on a set of Roosts or Whiskbroom does the Business No

Trouble, No Expense, a Child Can Do It.

The Traps only need to be emptied once every One Single Vermin Trap Roost Bar, 8 feet long, ten days and 3 or 4 times is all that is necessary min Trap Roosts will weigh 35 lbs., crated, and go to rid your fowls and hen houses of mites, bed- by third class freight.

bugs, spider-lice and all blood sucking lice. They Every Roost Bar is fitted with a malleable iron are easy to kill, simply brush the lice in the traps flat hook at each end to fit an inch board, and is out in a bucket of hot water or fire. Any ten yearleasily put in any hen house.

\section{“SAVE-AL” Guaranteed Egg Preservative}

A Tasteless, Odorless Preparation that Will Keep Fresh Eggs in Excellent Condition Six to Ten Months-One Gallon Sufficient for 65 Dozen Eggs

Save-Al positively will keep strictly fresh eggs intween a fresh-laid egg purchased in the open marusable and marketable condition for ten monthsket and eggs which had been put down in Save-Al. if it is desired to hold them that long. And it saves We recommend the use of Save-Al to all who ALL the eggs, not merely some of them. Save-Aldesire to save money by preserving eggs when is easy to use and is absolutely safe and sure. Onecheap and to have plenty for use when they are gallon makes sufficient solution to preserve 65 scarce and high-priced.

dozen eggs in perfect condition for 10 months. Prices: Half-gal. cans, 50c; 1-gal. cans, 90c. Eggs preserved in Save-Al are superior in everyspecial prices on 10, 20 and 50-gal. casks.

way to limed eggs. The solution has been thor- Parcel Post weights: Half-gal. can, 8 lbs; oughly and carefully tested, and critical observers1-gal. can, $15 \mathrm{lbs}$.

have found it difficult to detect the difference be-

\section{Planet, Jr. Farm and Garden Tools}

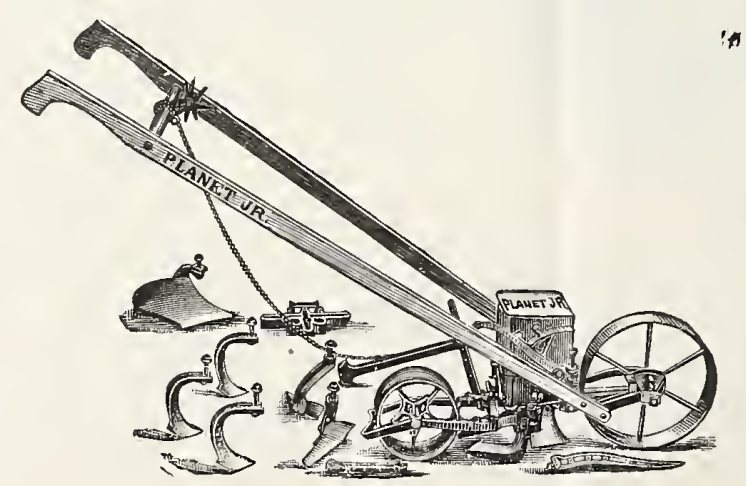

We have in stock a full assortment of Planet Jr.|cular and quote prices at any time if you are intergarden tools. These garden tools are in a class ested.

by themselves. We would be glad to hand you cir- 


\section{ORDER SHEET TO \\ THOMPSON BROTHERS CO.}

Wholesale and Retail

\section{Garden, Field and Flower Seeds \\ MUSGATINE, IOWA}

NOTICE-While we exercise great care to have all seeds, and bulbs and plants pure and reliable, we sell none with warranty, expressed or implied in any respect, and we will not in any way be responsible for results. If the purchaser does not accept the goods on these terms they must be returned at once.

SEND BY

State if wanted by Mail, Express (and Company); Freight and Route.

TO (Name)

POST OFFICE

(Very Plainly)

COUNTY

STATE

STREET OR RURAL DELIVERY

P. O. BOX

FREIGH'T OR EXPRESS OFFICE $\begin{gathered}\text { If different } \\ \text { from P. O. }\end{gathered}$

QUANTITY




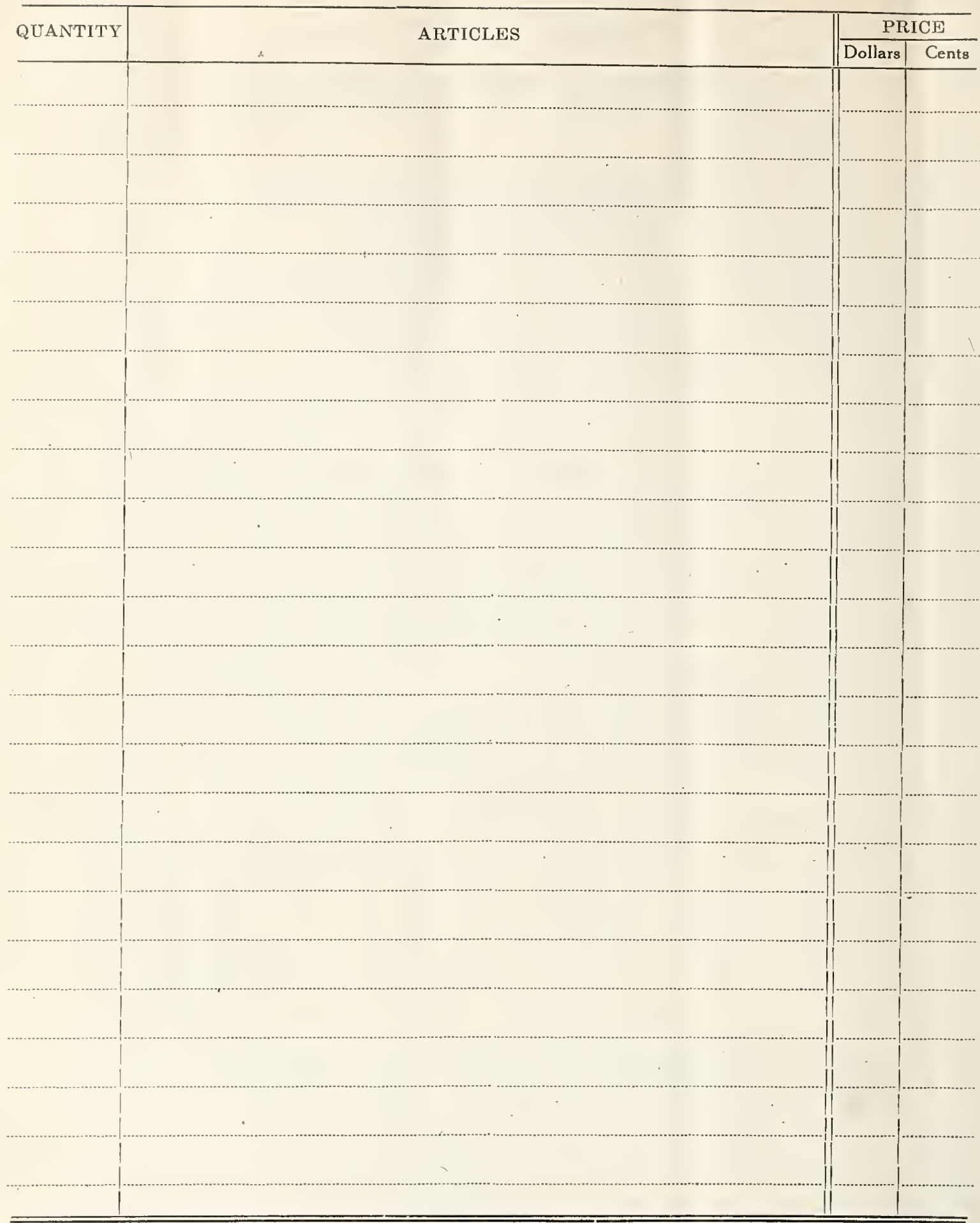

\section{CUSTOMERS PTEASE DO NOT WRITE IN THIS SPACE}

Route Shipped by in........ Pkgs..........Bundles .........Boxes.

The following articles will be sent later.
Checked by
Date Shipped

Crates........... Baskets............Bbl. Bags 


\section{THE IDEAL WATERERS}

\section{Ideal Hog Waterer Styles}

\section{No. 4,5 and 6}

An absolutely sanitary waterer that will not freeze in winter and keeps the water cool, fresh and clean in the summer. An all-the-year-around waterer. Every hog raiser knows that good, clean water is an absolute necessity in raising hogs and chickens to get the most out of them. Hogs and poultry are two of the best paying crops you raise and the bettel care they receive the more profit they make for you.

A hog wants water irrequently-he will leave $h$ is feed and take a few swallows of water if the water is convenient for them. They requile lots of wa-

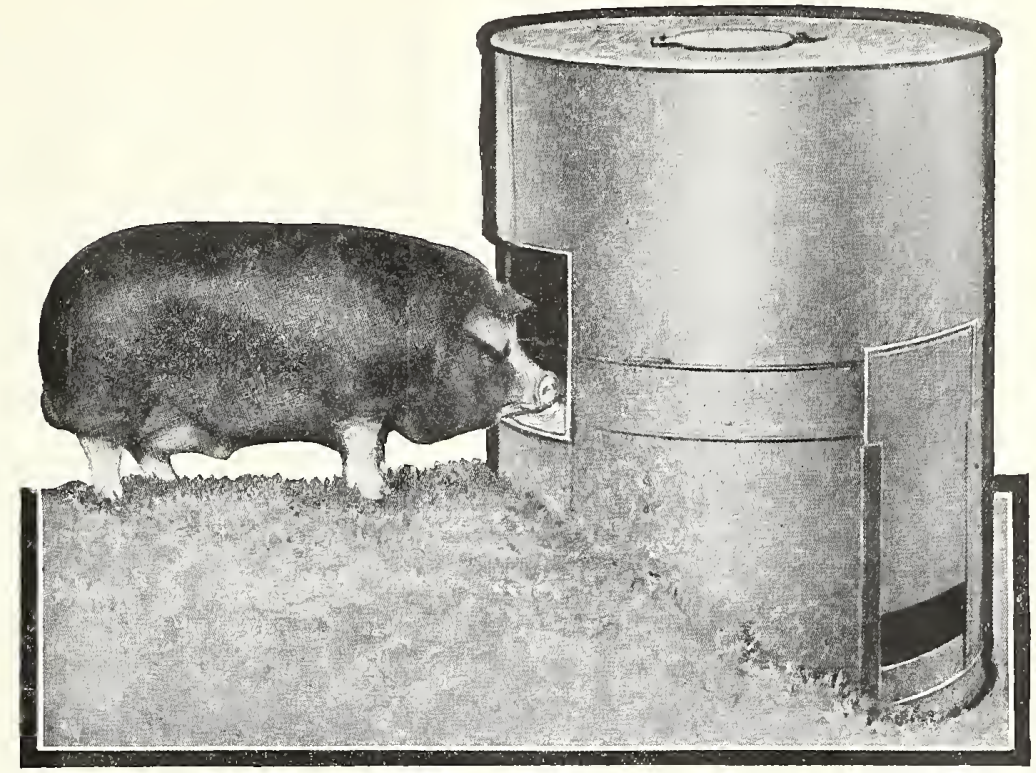
ter to digest their food properly and keep the system in a good healthy condition. A hog consumes from 7 to 8 pounds of water for each pound of dry matter eaten-nearly twice as much as horses and cattle.

Your growing hogs or brood sows should never be given ice cold water. They cannot keep as healthy, grow and produce as well if their entire body is thoroughly chilled two or three times a day with cold water. You have seen hogs hesitate about drinking cold water, but when real thirsty they drink more than they should and then stand for an hour all humped up and shivering. Their entire body is chilled; their food is not thoroughly digested and a part of the nutrition they do get from the corn goes to heat the body instead of producing fat.

You can positively save 25 per cent of your feed cost by giving your hogs a constant supply of good, clean water, with the chill off just as they want it.

A hog will live and put on weight for 4 or 5 days with practically no food if he is given all the water he wants, but he will begin to lose weight in two days if he has no water, even though he has all the corn he wants.

Nearly two-thirds of a hog's body is water. Give them all they will drink. Water is cheap-corn costs money. Plenty of pure water is a big help toward preventing disease.

One of the hardest chores on the farm is to properly water the hogs, especially in cold, zero weather when the water freezes in the trough in half an hour. It is a hard job to chop ice from the trough two or three times a day to give the hogs fresh water, and even then they do not have water as often as they should. With an Ideal Waterer your hogs can have a constant supply of good, clean water with the chill off just as they want it, night and day. Hogs will drink frequently both night and day if the water is convenient and the right temperature.

With the tank style of Waterers the water is automatically fed to the drinking pan by the vacuum system so there are no valves or other mechanism to get out of order. The trough is always full but never overflows. No mud hole or disease breeding place around the drinking troughs.

The drinking trough is thoroughly protected so horses or cattle cannot step into it or damage it, and hogs cannot get into it with their feet to foul or waste the water, but they can always have all they want to drink.

In the top of the tank is a vacuum-no air or anything but just space. A complete vacuum is a non-conductor of heat and cold so this keeps the water cool in summer and helps to keep it warm in winter.

In cold weather the water that is exposed to the air will freeze first. There is no advantage in keeping water in a tank warm if it freezes in the trough where the hogs drink. You will note by the illustration that the lamp sets directly under the drinking pan so the water cannot freeze and the heat then passes up around the tank and keeps the water at just the right temperature.

"The Ideal Waterers have been used and worked perfectly with the thermometer at 35 degrees below zero.

The heat being properly applied as it is, and confined inside the casing the lamp can be turned low so it uses only a small amount of coal oil. It costs only 2 to 3 cents a day to keep the water warm night and day in the coldest weather.

An approach is built to the drinking trough so hogs of any size can drink.

The Ideal Waterers are made of heavy galvanized iron. They are strong and substantial and will last for years. They are shipped complete with lamp and metal chimney.

Sizes and Prices

No. 4-30-gallon Waterer, weight 80 lbs $\ldots \$ 14.50$ No. 5-60-gallon Waterer, weight $100 \mathrm{lbs} \ldots \mathbf{1 9 . 5 0}$ No. 52-60-gallon Waterer, with two drinking troughs, weight 100 lbs................. 22.50 No. 6-100-gallon Waterer, weight 140 lbs 27.00 No. 62-100-gallon Waterer, with two drinking troughs, weight 140 lbs.................... 30.00 
